\title{
Gefa viðbrögð við eldgosi innsýn í krísu- stjórnun: Dæmi frá Icelandair
}

\author{
Regína Ásdísardóttir, doktorsnemi, Viđskiptafræđideild Háskóla Íslands \\ og Runólfur Smári Steinpórsson, prófessor, Viðskiptafræđideild Háskóla \\ Íslands
}

\section{Útdráttur}

Eldgosið í Eyjafjallajökli árið 2010 hafði víðtæk áhrif á íslenskt samfélag, ekki síst á flugsamgöngur vegna öskuskýsins sem myndaðist við pað. Truflanir á flugi teygðu anga sína um stóran hluta Evrópu pannig að flugleiðir lokuðust og farpegar komust ekki leiðar sinnar. Icelandair fór ekki varhluta af ástandinu og stóð frammi fyrir miklum erfiðleikum við að halda uppi pjónustu við farpega sína. Viðfangsefni pessarar greinar er að skoða hvort og hvernig raundæmi frá Icelandair, par sem viðbrögð félagsins eru rakin pegar truflanir vegna gossins voru mestar, gefi innsýn í krísustjórnun. Um könnunarrannsókn er að ræða og tilgangurinn er að átta sig á ýmsum breytum og áhrifapáttum krísustjórnunar og draga fram áhugaverðar spurningar til frekari skoðunar. Gerð er grein fyrir hugtökunum krísa og krísustjórnun, atburðarás og viðbrögð Icelandair eru rakin, og niðurstöður dregnar saman í svörum við rannsóknarspurningunum sem lagðar eru fram. Helstu niðurstöður eru í fyrsta lagi að skilgreina má ástandið sem skapaðist hjá Icelandair í kjölfar gossins sem krísuástand. Í öðru lagi að krísuteymi, upplýsingamiðlun og samstarf við hagsmunaaðila hafi verið veigamiklir pættir í viðbrögðum félagsins. Í priðja lagi að viðbrögð Icelandair hafi vegna sérstöðu krísunnar verið byggð á reynslu og pekkingu félagsins og að framvinda athafna hafi verið um margt sjálfsprottin.

Efnisorđ: Eldgos, krísa, krísustjórnun, rekstraráhætta, sjálfsprottnar athafnir. 
STJÓRNSÝSLA

\title{
Do reactions to volcanic eruptions give insight into crisis management: An example from Icelandair
}

\begin{abstract}
The 2010 volcanic eruption in Eyjafjallajökull had an extensive impact on the Icelandic society, especially on air traffic due to the volcanic ash cloud which emerged. Flight disturbance also occurred in large parts of Europe, causing air routes to close down, hindering passengers to proceed with their travelling. Icelandair, Iceland's largest airline company, was hugely affected by this extreme situation, which made the continuing of operations a great challenge. The subject of this article is to investigate whether and how a case study on Icelandair's reactions, during the peak of disturbance on operations, can give an insight into crisis management. The research is explorative with the purpose of understanding various variables and influencing factors on crisis management and to bring out interesting questions for future investigations. In the article the concepts of crisis and crisis management are defined, the course of events and Icelandair's reactions are expounded, and results and conclusions are summarized in answers to the research questions. The main conclusions are; first that the situation that occurred in Icelandair because of the volcanic eruption can be defined as a crisis. Second, that a crisis committee, information and co-operation with stakeholders were important factors in the company's reaction. Third, that due to the particular type of crisis in question, based on the experience and knowledge within the company, Icelandair's reactions unfolded as emergent activities.
\end{abstract}

Keywords: Volcanic eruption, crisis, crisis management, operational risk, emergent activities.

\section{Inngangur}

Gosið í Eyjafjallajökli vorið 2010 hafði á nokkrum klukkustundum lamandi áhrif á marga pætti í nærsamfélaginu á Íslandi og var ekki síður afdrifaríkt fyrir flugsamgöngur í Norðvestur Evrópu. Kraftmikill öskustrókurinn náði strax 10 km hæð og gríðarlegt öskuskýið dreifðist hratt með háloftavindi, til Norður og Vestur Evrópu (Tamagno, 2010). Um 104.000 flugferðum var aflýst á tímabilinu 15.-22. apríl og um 10 milljónir manna urðu fyrir verulegum töfum vegna atburðarins og purftu að breyta ferðaáætlunum sínum (Eurocontrol, 2010). Pessar óvenjulegu aðstæður röskuðu áætlanaflugi í Evrópu verulega og tap flugfélaganna sem áttu í hlut varð í heild um 1.7 milljarðar dollara (IATA, 2010). Vegna vindáttar í háloftunum fyrstu dagana til suðausturs hafði gosið lítil áhrif á flug um Keflavíkurflugvöll. Icelandair gat haldið upp flugi vestur um haf og stjórnendur félagsins höfðu ráðrúm til að bregðast við aðstæðum við skipulag á flugi til Norður Evrópu. Meðan á gosinu stóð tókst Icelandair að skila um 80\% farpega sinna á áfangastað (Guðjón Arngrímsson, munnleg heimild, 8. apríl 2011, i Anna Anita Jónsdóttir, 2011) og árið 2010 reyndist besta rekstrarár félagsins frá upphafi (Icelandair, e.d.). 


\section{STJÓRNMÁL \& \\ STJÓRNSÝSLA}

Í pessari grein er viðfangsefnið að rýna í atburðarásina hjá Icelandair við að halda uppi pjónustu og skila farpegum sínum á áfangastað meðan á gosinu stóð. Icelandair gaf rannsakendum heimild til pess að fara ofan í fyrirliggjandi gögn og afla frekari upplýsinga um ferlið sem átti sér stað varðandi hvernig félagið og teymið sem var að bregðast við krísunni starfaði pessa annasömu daga meðan á gosinu stóð. Hér er litið svo á að Icelandair sé að bregðast við krísu með tilteknum hætti sem flokka má undir krísustjórnun. Í íslenskum rannsóknum hefur einnig verið notast við hugtökin áfall og áfallastjórnun um petta sama fyrirbæri (Ásthildur Elva Bernharðsdóttir og Gunnar Helgi Kristinsson, 2003).

Rannsakendur höfðu sérstakan áhuga á pví að kanna hvernig fyrirtæki eins og Icelandair ber sig að í starfsemi sinni pegar upp koma fyrirvaralausar og mjög erfiðar aðstæður. Slíkar aðstæður eru á ensku nefndar „extreme situations“ og áhugi fræðasamfélagsins á pví hvernig fyrirtæki og stofnanir bregðast við pegar mikið liggur við er bæði pó nokkur og vaxandi (sjá Wooten og James, 2008; James og Wooten, 2005; James o. fl., 2011; Hannah o. fl., 2009; Fisher o. fl., 2010; Duncan o. fl., 2011; Bowden, 2011; Lettieri o. fl., 2009; Alvarez o. fl., 2011; Melkonian and Picq, 2010, 2011; Récopé o. fl., 2010; DeChurch o. fl., 2011; Bouty o. fl., 2012). Til að skerpa enn frekar sjónarhólinn á atburðarásina hjá Icelandair meðan á eldgosinu stóð var fókusinn settur á að skoða atburðinn sem krísu og spyrja hvort stjórnun hjá Icelandair á pessum tíma eigi sér samsvörun við krísustjórnun.

Eldgos eru náttúruhamfarir og slíkar aðstæður geta valdið krísum (Perrow, 1984). Jafnan er litið á hamfarir sem óviðráðanlegt ástand og pær geta skapað pað sem Gundel (2005) skilgreinir sem undirstöðukrísu (e. fundamental crisis) af pví að öllum grundvelli getur mögulega verið kippt undan tiltekinni starfsemi. Krísu af pessu tagi er erfitt að sjá fyrir og erfitt að ná tökum á. Krísur geta líka komið upp af öðrum ástæðum og fyrir eigin tilverknað (Faulkner, 2001). Einnig eru fyrirliggiandi kenningar um hvernig megi bregðast við krísum (Pearson og Mitroff, 1993; Pearson og Clair, 1998; Santana, 2003; Ritchie, 2004; Wang og Ritchie, 2010, 2012). Rannsóknir á krísustjórnun á Íslandi hafa verið af skornum skammti. Helst má nefna verk Ásthildar Elvu Bernharðsdóttur (2001), Ásthildar Elvu og Gunnars Helga Kristinsonar (2003) og Ásthildar Elvu og Svedin (2004). Einnig hafa verið skrifaðar meistararitgerðir um efnið (Óskar Örn Árnason, 2009; Kristinn Jón Bjarnason, 2009; Birna Ósk Hansdóttir, 2009; Halla Valgerður Haraldsdóttir, 2010; Regína Ásdísardóttir, 2012). Pað er von höfunda að pessi rannsókn sem hér er greint frá sé bæði frekara innlegg í pekkingaröflun á krísustjórnun við íslenskar aðstæður og ekki síður hvatning til að auka og efla rannsóknir á fyrirbærinu hérlendis.

Í rannsókninni er leitað svara við eftirfarandi rannsóknarspurningum:

- Að hvaða marki má lýsa aðstæðum Icelandair meðan á gosinu stóð sem krísu?

- Hvernig brugðust stjórnendur og starfsfólk Icelandair við ástandinu?

- Hvaða lærdóm má draga af viðbrögðum Icelandair með hliðsjón af krísustjórnun? 
Rannsóknin á hinni tilgreindu atburðarás hjá Icelandair og viðbrögðum stjórnenda meðan á gosinu í Eyjafjallajökli stóð er skilgreind sem raundæmisrannsókn (Yin, 1989). Markmiðið er að kortleggja atburðarásina og ná yfirsýn yfir ferlið og fá innsýn í viðbrögð stjórnenda Icelandair, sérstaklega sjálfsprottin viðbrögð. Fræðasviðið sem reynslan frá Icelandair er borin saman við er krísustjórnun og leitað er eftir ólíkum nálgunum að krísustjórnun. Til að auðvelda umræðu og gera mögulegt að svara rannsóknarspurningunum er gerð grein fyrir fyrirliggjandi pekkingu um krísur og krísustjórnun. Eins og ráða má af titli greinarinnar pá er kveikjan að pessu verki spurningin um pað hvort viðbrögð við gosinu í Eyjafjallajökli geti gefið innsýn í krísustjórnun. Dessi rannsókn sem hér er greint frá er hluti af stærra rannsóknarverkefni höfunda um einkenni stjórnunar og skipulags við knýjandi aðstæður og pegar er fyrirliggjandi ein ritgerð tengd pessu verkefni (Regína Ásdísardóttir, 2012). Frekari rannsóknir og birtingar á niðurstöðum eru fyrirhugaðar.

Uppbygging greinarinnar verður pannig að á eftir pessum inngangi og að loknum kafla um aðferðafræði rannsóknarinnar er dregið fram fræðilegt yfirlit yfir krísur og krísustjórnun. Síðan er rýnt í dæmið um Icelandair og atburðarásina meðan á gosinu stóð. Að endingu eru svörin við rannsóknarspurningunum dregin fram með hliðsjón af hinni fræðilegu afmörkun og athugað hvaða samsvörun megi finna á milli peirrar stjórnunar hjá Icelandair sem skoðuð er og krísustjórnunar.

\section{Aðferðafræði}

Rannsóknin sem gerð var er skilgreind sem raundæmisrannsókn. Raundæmið er tiltekin atburðarás hjá Icelandair og hvernig félagið brást við knýjandi og erfiðum aðstæðum meðan á gosinu í Eyjafjallajökli stóð. Til að varpa ljósi á aðferðafræðina er hér að neðan fjallað um raundæmisrannsóknir almennt séð og svo framkvæmd rannsóknarinnar.

\section{Raundæmisrannsóknir}

Með raundæmisrannsókn er átt við Case Study Research (Yin, 1989). Aðrar býðingar á pessari aðferðafræðilegu nálgun eru t.d. raunrannsókn (Runólfur Smári Steinpórsson, 1995) og tilviksrannsókn (Guðrún Stefánsdóttir, 2000; Arna H. Jónsdóttir, 2001). Samkvæmt Yin (1989) eru megineinkenni raundæmisrannsókna pau að verið er að rannsaka eitt eða fleiri dæmi sem varpa ljósi á tiltekið fyrirbæri í raunveruleikanum með margs konar gögnum.

раð hentar einkum að nota raundæmisrannsókn pegar eftirfarandi á við: Í fyrsta lagi ef rannsóknarspurningar byrja á spurnarfornöfnunum hvað, hvernig og hvers vegna. Í öðru lagi ef rannsakandinn getur ekki haft stjórn á peirri atburðarás eða peim breytum sem til skoðunar eru. Í priðja lagi hentar aðferðin pegar rannsóknin miðast að fyrirbæri í samtímanum (Yin, 1989; Runólfur Smári Steinpórsson, 1991; Robson, 2002; Bryman, 2008). Algengt er að beita raundæmisrannsóknum á fræðasviðum sem falla undir viðskiptafræði (Dul og Hak, 2008) og pað má útfæra rannsóknirnar með mismunandi hætti allt eftir pví hvort um eitt dæmi eða fleiri er að ræða og hvort dæmi(n) eru afmörkuð heildrænt (e. holistic) eða í samofnum lögum (e. embedded) (Yin, 1989). Við val á rann- 
sóknarsniði er mikilvægt að huga að tilgangi rannsóknarinnar og framkvæmd hennar (Ghauri og Grönhaug, 2002).

\section{Rannsóknin á atburđarás hjá Icelandair í gosinu í Eyjafjallajökli}

Raundæmisrannsóknin var skilgreind sem könnunarrannsókn par sem leitast var við að ná utan um og skapa skilning á viðfangsefninu. Jafnframt var litið á atburðarásina sem eitt heildrænt dæmi. Stjórnendur Icelandair reyndust mjög hjálplegir pegar kom að gagnaöflun um atburðarásina og peir heimiluðu að rannsakendur gætu stuðst við skýrslu sem Icelandair lét gera. Skýrslan hefur titilinn „Flogið framhjá öskunni“ og hefur að geyma lýsingu á atburðum og tilvitnanir í stjórnendur Icelandair sem upplifðu krísuna og áttu pátt í krísustjórnuninni. Auk pessarar heimildar var leitað til tveggja stjórnenda beint og byggt á gögnum úr fjölmiðlum um pessa daga sem liðu meðan á gosinu stóð. Við túlkun á gögnunum er pess gætt að horfa gagnrýnið á pau, bæði með hliðsjón af rannsóknarspurningunum og nálguninni í rannsókninni sem hefur verið lýst hér að framan.

Rétt er að undirstrika að rannsóknin er skilgreind sem könnunarrannsókn og afmarkast við eitt dæmi. Tilgangurinn er ekki að alhæfa um krísustjórnun fyrirtækja og stofnana, heldur að átta sig á ýmsum breytum og áhrifapáttum krísustjórnunar og draga fram áhugaverðar spurningar til frekari skoðunar. Raundæmisrannsóknir hafa verið gagnrýndar vegna pess að ekki sé hægt að alhæfa út frá niðurstöðum peirra (Paraskevas, 2006). Samkvæmt Yin (1994) er í pví sambandi mikilvægt að gera greinarmun á annarsvegar tölfræðilegum alhæfingum og alhæfingum sem snúa að framlagi til fræðilegrar pekkingar. Í pessari rannsókn sem hér er greint frá eru reynslugögn sett í samhengi við fræði um krísur og krísustjórnun og eru niðurstöður rannsóknarinnar hugsaðar sem framlag til frekari pekkingar á krísustjórnun pegar glímt er við erfiðar ytri aðstæður.

\section{Krísur og krísustjórnun}

Til að draga lærdóm af viðbrögðum og atburðarás í rekstri Icelandair meðan á gosinu í Eyjafjallajökli stóð með hliðsjón af krísustjórnun parf að gera nánari grein fyrir hugtökunum krísu (e. crisis) og krísustjórnun (e. crisis management). Innan fræðanna virðist vera nokkur samhljómur um eðli og umfang krísustjórnunar í skipulagsheildum (Wang, Hutchins og Garavan, 2009) en pað hefur reynst áskorun fyrir fræðimenn að sammælast um skilgreiningu á krísu. Hugtakið hefur verið notað á mörgum ólíkum vísindasviðum og skilgreiningar fara gjarnan eftir sjónarhorni pess sem skilgreinir pað (Armstrong, 2008; Ritchie, 2009; Preble, 1997). Par sem hér er um tiltölulega ungt fræðasvið аð ræða er leitast við að greina frá helstu skilgreiningum sem settar hafa verið fram og síðan draga fram pá skilgreiningu sem stuðst er við í greiningu á raundæminu.

\subsection{Hvað er krísa?}

Til að skapa skilning á hugtakinu krísu hefur verið bent á eðli og eiginleika krísunnar. Einnig hefur verið varpað ljósi á flækjustig og kaótískt eðli atburðanna sem eiga sér stað (Ritchie, 2004). Samkvæmt Institute for Crisis Management (ICM) má finna í skilgreiningum á krísum að pær gerast skyndilega, krefjast skjótra viðbragða, trufla frammistöðu 
skipulagsheilda, skapa óöryggi og streitu, ógna orðspori, stigmagnast í styrkleika og að krísa breyti skipulagsheildinni til frambúðar. Enn fremur að krísa valdi verulegri truflun í fyrirtækjum eða viðskiptum, sem aftur valdi umfangsmikilli fjölmiðlaumfjöllun og síðan grandskoðun almennings sem hefur áhrif á hefðbundna starfsemi skipulagsheildar sem svo getur haft pólitísk, lagaleg og fjárhagsleg áhrif á skipulagsheildina (ICM, 1996; ICM, e.d.). Í fræðum um skipulagsheildir (e. organizational literature) varðandi hugtakið krísu er oftast litið til eftirfarandi skilgreiningar: Krísa er áhrifamikill, sjaldgæfur atburður sem ógnar tilvist viðkomandi skipulagsheildar og einkennist af atburðarás par sem erfitt er að átta sig á orsökum og afleiðingum sem og hvernig beri að bregðast við, um leið og pað er knýjandi að teknar séu ákvarðanir um aðgerðir (Pearson og Clair, 1998).

Í fræðilegri samantekt Sayegh o.fl. (2004) um krísur kemur fram að höfuðeinkenni krísu í skipulagsheild sé mikil margræðni með ópekktum orsökum og áhrifum. Að krísa sé sjaldgæfur, óvenjulegur og ópekktur atburður sem kalli á skjót viðbrögð. Að skipulagsheildinni og hagsmunaaðilum standi mikil ógn af krísum og að pörf sé fyrir skjóta ákvarðanatöku sem geti haft jákvæðar eða neikvæðar afleiðingar. Pauchant og Mitroff (1992) skilgreina krísu sem truflun sem hefur ápreifanleg áhrif á viðkomandi kerfi í heild sinni og sem ógnar grunnhugmyndum, huglægri sjálfsmynd og kjarnanum í tilveru pess. Perrow (1984) hefur svo enn aðra nálgun í skilgreiningu sinni á eðli krísu. Hann flokkar krísu í prjá flokka: eðlilega (normal) krísu sem eru slys sem orsakast af ofhleðslu kerfa eða bilunum, óeðlilega (abnormal) krísu sem eru ráðgerðir atburðir sem ætlaðir eru til pess að valda eyðileggingu, ótta eða skelfingu, og í priðja lagi krísu af völdum náttúruhamfara.

Раð er einnig gagnlegt að skoða skilgreiningu Selbst (1978). Hann skilgreinir krísu sem sérhverja aðgerð eða skort á aðgerð sem truflar yfirstandandi starfsemi skipulagsheildar, truflar ásættanlegan árangur skipulagsheildar í að ná markmiðum sínum og sem getur haft áhrif á hæfni hennar til pess að lifa af eða haft skaðleg persónuleg áhrif frá sjónarhóli meirihluta starfsmanna hennar eða viðskiptavina. Faulkner (2001) útvíkkaði skilgreiningu Selbst og aðgreindi hugtökin krísu og hamfarir. Hann telur hið fyrrnefnda að einhverju leyti sjálfskapað ástand en hamfarir verða af óviðráðanlegum orsökum. Svipaða tvískiptingu er að finna hjá Rosenthal og Kouzmin (1993) og Gundel (2005). Jafnframt bætir Faulkner við að útkoma eða afleiðing krísu geti verið jákvæð en ekki eingöngu neikvæð en sama sjónarmið er einnig að finna í samantekt Faulkners á framlagi Fink (1986), Keown-McMullan (1997) og Weiner og Kahn (1972). Að mati Miller og Ritchie (e.d.) er greinarmunurinn á krísu eða hamförum afar mikilvægur pegar kemur að pví að bregðast við atburðum. Krísa kallar á breytingar til pess að koma í veg fyrir að atburðir geti leitt til krísuástands á ný, á meðan hamfarir krefjast viðbragða til pess að takmarka áhrifin ef hamfarirnar skyldu endurtaka sig (Carter, 1991).

Ofangreint sýnir mismunandi skilgreiningar á krísu. Í pessari grein er lögð sú merking í hugtakið krísu að um sé að ræða fyrirvaralaust, ópekkt og ósennilegt ástand sem geti haft gífurleg áhrif, sem ýmist er hrundið af stað af fólki, skipulagsformum, efnahagsaðstæðum, tækni eða af náttúruhamförum (Pearson og Clair, 1998; Reilly, 1987; Rosenthal, Boin og Comfort, 2001). 
Í fræðum um krísur og krísustjórnun kemur fram að krísa hefur verið flokkuð á ýmsan hátt. Í grófum dráttum má skipta krísum í tvo flokka; annars vegar krísur sem verða vegna ytri áhrifa og hinsvegar krísur sem eru sjálfskapaðar. Lerbinger (1997, í Stafford, Yu og Armoo 2002) hefur gengið aðeins lengra í pessari flokkun. Hann flokkar krísur sem herjað geta á fyrirtæki (e. business crisis) í prjá breiða flokka eftir umhverfisgerð og í sjö undirflokka sem sjá má á mynd 1. Dessir prír umhverfisflokkar eru; ápreifanlegt umhverfi (e. physical environment), mannlegt eða félagslegt umhverfi, og stjórnunarbrestur, (e. management failure). Hinar sjö undirtegundir krísu eru; náttúruhamfarir, tæknilegur brestur, ágreiningur (e. confrontation), illvilji (e. malevolence), brenglað gildismat (e. skewed values), blekkingar (e. deception) og að síðustu misferli (e. misconduct).

priðja aðgreiningin, krísur af félagslegum orsökum, hefur einnig verið notuð til flokkunar (Rike, 2003). Dessi priggja flokka aðgreining eru að vissu leyti gagnleg, sér í lagi til pess að skilgreina orsakir krísu en er pó umdeild. Röksemdafærsla gagnrýnenda er sú að nær ógerlegt sé að aðgreina margpættar, oft tengdar en pó landfræðilega dreifðar orsakir krísu sem grundvallast á peirri staðreynd að nútíma krísur eru oft og tíðum viðvarandi (Rosenthal og Kouzmin, 1993). Engu að síður virðast algengustu nálganir pegar krísur eru flokkaðar í mismunandi tegundir, byggja á aðgreiningu milli orsaka eða aðaleinkenna krísunnar (Gundel, 2005). Gundel sem er einn gagnrýnenda pessara hefðbundnu flokkana, hefur lagt til nýja flokkunaraðferð sem byggir á tveimur víddum; í fyrsta lagi hversu fyrirsjáanleg krísan er (e. predictability) og í öðru lagi að hvaða marki er hægt að

Mynd 1. Tegundir af krísum sem herja á fyrirtæki. (Lerbinger, 1997, í Stafford, Yu og Armoo, 2002)

\begin{tabular}{|c|c|c|c|}
\hline Stærri áhrifapættir & Umhverfispættir & Tegund krísu & Dæmi um krísu \\
\hline \multirow{4}{*}{ Ytri pættir } & \multirow{2}{*}{$\begin{array}{l}\text { Ápreifanlegt } \\
\text { umhverfi }\end{array}$} & Náttúruhamfarir & $\begin{array}{l}\text { Jarđskjálfti leggur hótel í } \\
\text { rúst; eldgos hræðir } \\
\text { ferđamenn frá }\end{array}$ \\
\hline & & Tæknibrestur & $\begin{array}{l}\text { Olíuleki mengar } \\
\text { ferđamannaströnd og } \\
\text { aftrar ferðamönnum að } \\
\text { ferðast pangað }\end{array}$ \\
\hline & \multirow{2}{*}{$\begin{array}{l}\text { Mannlegt eđa } \\
\text { félagslegt umhverfi }\end{array}$} & Ágreiningur & $\begin{array}{l}\text { Verkfall truflar eðlilegan } \\
\text { rekstur; } \\
\text { hagsmunasamtök } \\
\text { sniðganga veitingastað }\end{array}$ \\
\hline & & Illvirki & $\begin{array}{l}\text { Hryðjuverkaárás; eitur } \\
\text { sett í matvæli; tölvuvírus } \\
\text { settur af stað i tölvukerfi }\end{array}$ \\
\hline \multirow[b]{2}{*}{ Innri pættir } & \multirow[b]{2}{*}{ Bresturí stjórnun } & Brenglað gildismat & $\begin{array}{l}\text { Farbegaskip losar olíu í } \\
\text { sjóinn }\end{array}$ \\
\hline & & Blekking & $\begin{array}{l}\text { Veitingastaður ber } \\
\text { viljandi fram ónýtan eđa } \\
\text { eitrađan mat }\end{array}$ \\
\hline
\end{tabular}




\section{STJÓRNSÝSLA}

Mynd 2. Fylki Gundel sem sýnir fjórar tegundir krísu. (Gundel, 2005)

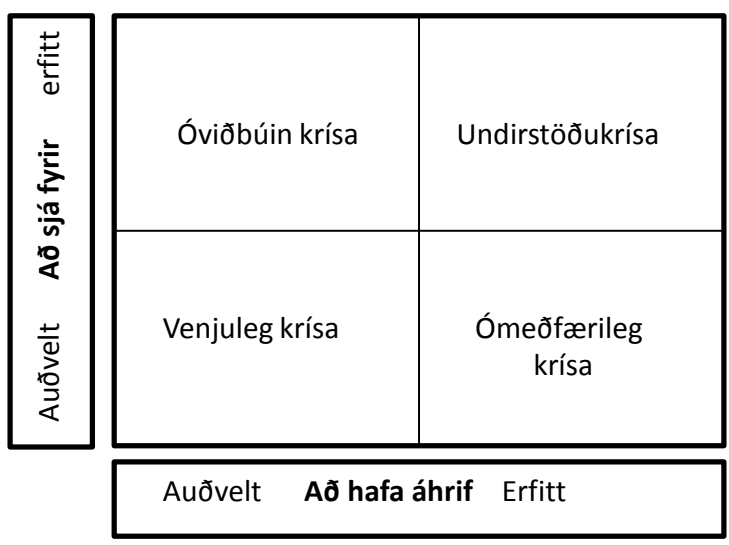

hafa áhrif á hana (e. influence possibility) áður en krísan skellur á og sérstaklega meðan á henni stendur. Gundel setur flokkun sína fram í fjögurra reita fylki eins og sýnt er á mynd 2. Í fylkinu má sjá eftirfarandi fjórar tegundir krísu; venjuleg krísa (e. conventional crisis), óviðbúin krísa (e. unexpected crisis), ómeðfærileg krísa (e. intractable crisis) og undirstöðukrísa (e. fundamental crisis).

Ofangreind flokkun gerir mögulegt af afmarka enn frekar pá skilgreiningu á krísu sem stuðst er við í greininni, p.e. að um sé að ræða fyrirvaralaust, ópekkt og ósennilegt ástand sem hrundið er af stað af náttúruhamförum og sem geti ógnað grundvelli fyrir rekstur viðkomandi fyrirtækis.

\subsection{Krísustjórnun}

Krísustjórnun hefur verið skilgreind á mismunandi vegu pó samhljómur sé nokkur. Krísustjórnun hefur m.a. verið skilgreind sem viðvarandi kerfisbundin viðleitni skipulagsheilda til pess að bera kennsl á og koma í veg fyrir hugsanlega áhættu og vandamál og svo bregðast við peim vanda sem upp kemur með pað fyrir augum að draga úr skaða og grípa tækifæri ef slík gefast. Jafnframt að leita leiða til lærdóms, áætlanagerðar og pjálfunar, að teknu tilliti til hagsmuna viðeigandi aðila (Wang og Ritchie, 2012, 2010; Santana, 2003). Á svipuðum nótum skilgreina Pearson og Clair (1998) krísustjórnun sem safn aðferða sem notaðar eru til pess að viðhalda eða endurheimta eðlilega starfshætti, lágmarka skaða hagsmunaaðila og að draga lærdóm af krísum til pess að bæta stjórnun í viðkomandi skipulagsheild.

Einn páttur krísustjórnunar er gerð áætlana um viðbrögð við krísum (e. crisis management plan), sem samanstendur oftast af fjórum páttum; sjálfri áætluninni, krísuteymi, samskiptum, og að síðustu endurskoðun og endurmati slíkra áætlana og frammistöðu krísuteymis (Penrose, 2000). Slíkar áætlanir byggja á rökrænni nálgun (e. rationality) og fyrirhyggju varðandi hvernig krísan kunni að verða og hvernig fyrirtækið ætti að bregðast við (Paraskevas, 2006). Í hefðbundnum krísustjórnunarfræðum er mikil áhersla lögð á mikilvægi fyrirliggjandi áætlana varðandi hvernig bregðast skuli við krísum í fyrirtækjum sem taka bæði til tæknilegra atriða og óápreifanlegra hliða krísustjórnunar (Penrose, 
2000). Samkvæmt Penrose (2000) eru flestir rannsakendur á sviðinu sammála um að yfirleitt velti árangur krísustjórnunar á pví hvort áætlun um viðbrögð við krísu sé fyrir hendi eða ekki. Talið er að slík forvirk krísustjórnun geti dregið úr peim skaða sem krísa getur valdið. Gagnsemi fyrirbyggjandi áætlana er pó ekki óumdeild vegna peirrar óvissu sem krísum fylgir; flækjustig getur verið mikið og breytingar gerast jafnan hratt 1 krísuaðstæðum. Sumir fræðimenn hafa bent á nauðsyn krísustjórnunaráætlana til pess að takast á við pessa pætti (Penrose, Rasberry og Myers, 1997; Penrose, 2000), á meðan aðrir benda á að pessi rökræna nálgun að krísustjórnun sé einmitt veikleiki par sem krísur verði sífellt flóknari í eðli sínu og séu sífellt tengdari innbyrðis (Boin og Lagadec, 2000 í Paraskevas, 2006) og bví sé vaxandi krafa í fræðasamfélaginu um nýjar nálganir á krísustjórnun (Paraskevas, 2006). Áætlanir um viðbrögð við krísum einar og sér tryggja ekki endilega árangursríka krísustjórnun (Marra, 1998; Paraskevas, 2006), heldur hafa aðrir óápreifanlegir pættir einnig áhrif, til að mynda samskipti (Marra, 1998; Barton, 1993; Coombs, 2007; Millar og Heath 2003), sjálfræði (Marra, 1998; Penrose, 2000), forysta (Zhong og Low, 2009; Paraskevas et. al., 2013; Mitroff, 2004; James, Wooten og Dushek, 2011; Littlefield og Quenete, 2007; Pearson, 2005; Boin og t'Hart, 2003), og fyrirtækjamenning (Paraskevas et. al., 2013; Marra, 2004; Pauchant og Mitroff, 1992; Penrose, 2000).

Heath (1998) bendir á að vestræn fyrirtæki og stofnanir beiti jafnan krísustjórnun sem samanstandi af fjórum skrefum: 1) forvörnum (e. mitigation/prevention), 2) undirbúningi (e. preparation), 3) viðbrögðum (e. response) og 4) endurheimtu (e. recovery). Litið er á lærdóm sem nauðsynlegan pátt í krísustjórnun. Sömuleiðis er bent á að krísustjórnun feli yfirleitt í sér skref sem hjálpa við að koma auga á möguleg teikn um krísu, viðbragðsáætlun, samhæfingu aðgerða og áætlun um endurheimt (e. recovery) skipulagsheildar til fyrra horfs eftir krísu (Wang o.fl., 2009). Samkvæmt Hutchings og Wang (2008) hafa mörg líkön verið smíðuð til pess að sýna feril krísustjórnunar og vísa peir í pví sambandi til Elsubbaugh, Fildes og Rose (2004), Pearson og Claire (1998), Reilly (1993), Smits og Ally (2003) og Shrivastava (1993). Í hverju og einu líkani er svipuðum skrefum lýst varðandi hvernig skipulagsheildir stjórna og bregðast við krísu (Hutchings og Wang, 2008). Detta má sjá myndrænt í eftirfarandi líkani sem gefur yfirgripsmikla mynd af krísustjórnun (Pearson og Mitroff, 1993; Mitroff, 2005; Wang o.fl., 2009).

Mynd 3. Krísustjórnunarlíkan Pearson og Mitroff (Mitroff, 2005)

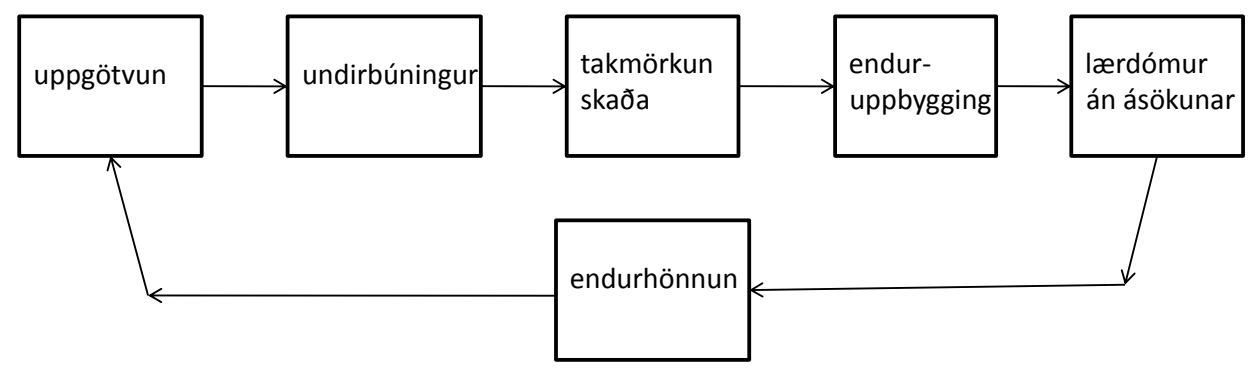




\section{STJÓRNSÝSLA}

Ritchie (2004) hefur gengið lengra í átt til forvirkrar krísustjórnunar og sett fram líkan að stefnumiðaðri krísustjórnun. Líkanið, sem sýnt er á mynd 4, var kynnt í framhaldi af ábendingu hans á pörfinni fyrir frekari próun á krísustjórnun innan ferðapjónustunnar. Ritchie hafði áður byggt á hugmyndum Faulkners (2001) um krísustjórnun í ferðapjónustu við rannsóknir sínar á Katherine flóðunum í Ástralíu 2001.

Mynd 4. Líkan Ritchie um stefnumiđađa krísustjórnun (Ritchie, 2004)

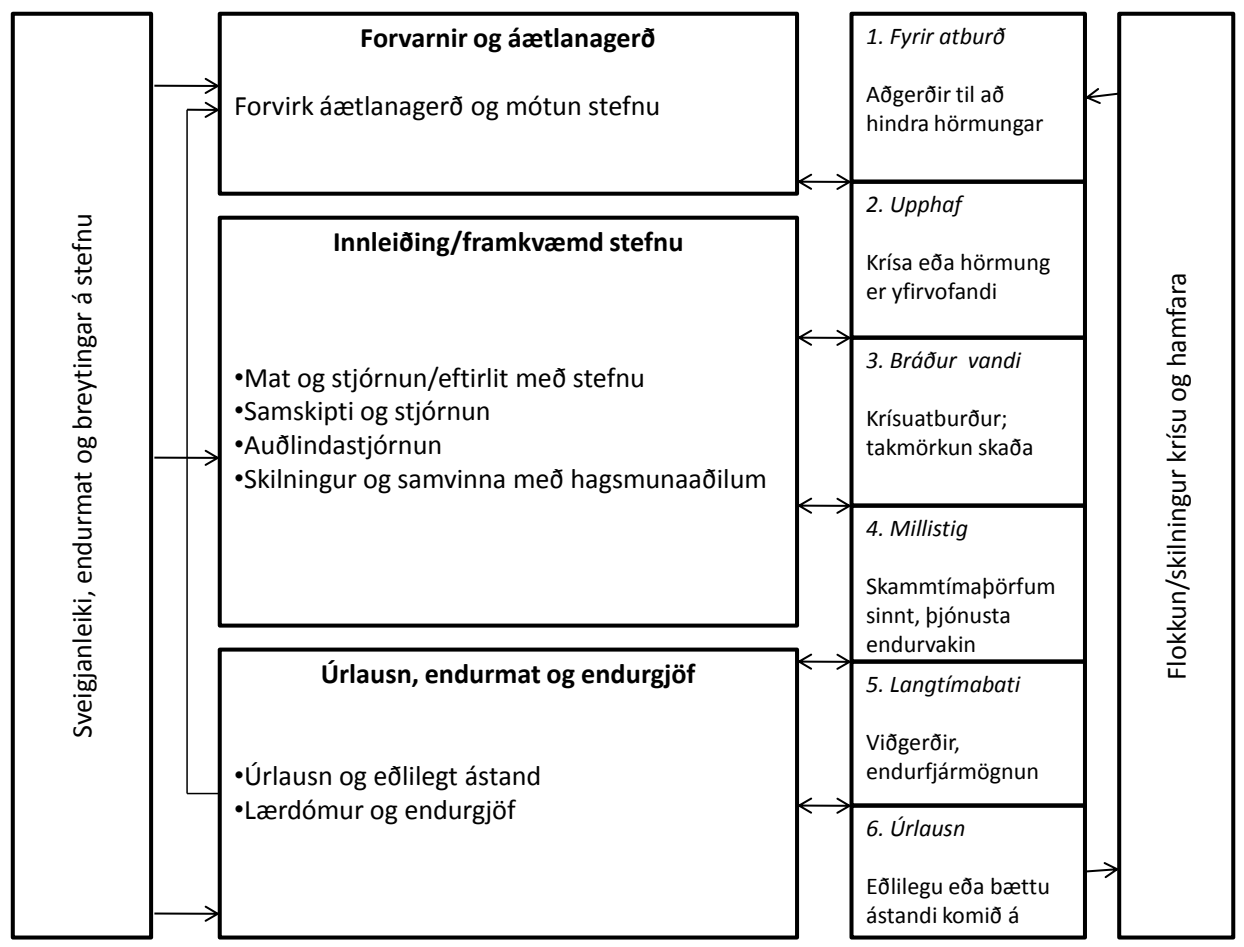

Með líkaninu leggur Ritchie til að stefnumiðuð stjórnun og áætlanagerð við krísustjórnun geti verið gagnleg fyrir stjórnendur í ferðapjónustu. Prjú megin stig líkansins; 1) forvarnir og áxtlanagerð, 2) innleiðing og 3) mat og endurgjöf kallast á við ábendingu Heath (1998) um að vestræn fyrirtæki og stofnanir styðjist yfirleitt við fjögur skref; 1) forvarnir, 2) undirbúning, 3) viðbrögð og 4) endurheimtu. Ritchie bendir á að líkan hans sýni algengustu einkenni (e. attributes) í krísustjórnun innan hvers skrefs í formi verkefna og athafna stjórnenda. Líkaninu er ætlað að nýtast við mismunandi gerðir af krísum, undirbúningur geti verið ólíkur og viðbragðsáxtlanir eftir pví. Í líkaninu er gert ráð fyrir sveigjanleika, endurmati og mögulegum breytingum á peirri stefnu sem fylgt er. Betta á við öll skref ferlisins og er pá tekið mið af viðbrögðum hagsmunaaðila og eðli krísunnar, s.s. umfangi, mikilvægi og tímapressu (Ritchie, 2004). 
Gefa viðbrögð við eldgosi innsýn í krísustjórnun.

Regína Ásdísardóttir og Runólfur Smári

Steinpórsson

\section{STJÓRNMÁL \& \\ STJÓRNSÝSLA}

\subsection{Rannsóknir á krísum og krísustjórnun}

раð er mikilvægt að hnykkja á pví að krísustjórnun er frekar ung fræðigrein sem er 1 próun. Fræðigreinin hefur fengið aukna athygli á síðustu áratugum (Argenti, 2007; Claudman og Hallahan, 2006), sér í lagi á níunda og tíunda áratugnum (Paraskevas o.fl., 2013; Rasmussen og Batstone, 1989). Samkvæmt Paraskevas o.fl. (2013) beindust rannsóknirnar einkum að krísum og samskiptum í kjölfarið á peim (Schultz og Seeger, 1991; Seeger, 1986; Sellnow, 1993), tengslum og samskiptum innri og ytri hagsmunaaðila (Kabak og Sionkos, 1990; Marcus og Goodman, 1991) og að samfélagslegum sjónarhornum (Bromiley og Marcus, 1989). Einnig var áhersla á rannsóknir á próun krísu (Fink, 1986; Smith, 1990) og stjórnun krísu (Mitroff, Shrivastava og Udwadia, 1987; Pauchant og Mitroff, 1992) sem byggðu á fyrri verkum Fink, Beak og Taddeo (1971) og Turner (1976). Verk Turner $(1976,1978)$ hrundu á sínum tíma af stað nýju stigi krísurannsókna, par sem aukið mið var tekið af mannlegum páttum í atvinnutengdum krísum en upphaflega hafði megináherslan verið á krísur af náttúrulegum völdum út frá samfélagslegum og landfræðilegum sjónarhornum (Smith og Elliot, 2006).

Samantekið pá stilla Paraskevas o.fl. (2013) rannsóknum á krísustjórnun á níunda og tíunda áratugnum upp í andstæður; Normal Accident Theory (La Porte, 1994; Perrow, 1994) og High Reliability Theory (Rochlin, 1993). Fyrri kenningin segir að krísur séu óhjákvæmilegar og eðlilegar, að pær gerist óviljandi og séu afleiðing flókinna kerfa nútíma skipulagsheilda. Seinni kenningin segir aftur á móti að skipulagsheildir geti með forvirkum hætti stjórnað og dregið úr áhættu á krísum (Sagan, 1993). Að mati Paraskevas o.fl. (2013) hafa pessar andstæður kallað fram uppbyggilega fræðilega umræðu um krísustjórnun sem hefur fært eftirfarandi pætti í brennidepil krísustjórnunarfræðanna; margbrotið eðli skipulagsheilda (e. organizational complexity), forystu, uppbyggingu (e. structure), menningu og að lokum ferli framkvæmda og lærdóms.

Á Íslandi hafa ekki verið gerðar margar rannsóknir á krísustjórnun sem eins og fram er komið hefur einkum verið nefnd áfallastjórnun. Svo virðist sem fyrirliggjandi rannsóknir hafi annars vegar verið gerðar út frá sjónarhorni stjórnmála- og stjórnsýslufræða varðandi aðkomu hins opinbera að krísum í kjölfar náttúruhamfara. Hins vegar má finna lokaritgerðir sem sækja efnivið sinn m.a. í viðbrögð fyrirtækja við peirri kreppu sem varð í kjölfar bankahrunsins á Íslandi. Samkvæmt Ásthildi Elvu Bernharðsdóttur (munnleg heimild, 21. ágúst, 2012) er erfitt að finna íslenskar rannsóknir um áfallastjórnun hjá fyrirtækjum.

Í ritgerð Ásthildar Elvu Bernharðsdóttur (2001) eru raundæmi um snjóflóðin í Súðavík og á Flateyri 1995 greind og borin saman með hliðsjón af áfallastjórnun hjá hinu opinbera og samvinnu pess við sjálfboðaliða, með áherslu á lærdómspátt áfallastjórnunar. Helstu niðurstöður voru að reynslan hafði ekki skilað sér með formlegum hætti til Almannavarna milli snjóflóðanna, heldur óformlega par sem margir sömu björgunarsveitarmanna komu að björgun í báðum snjóflóðunum. Tækifæri til lærdóms og aukinnar pekkingar var ekki nýtt sem skyldi par sem rannsóknarnefnd var ekki strax skipuð af ríkinu til pess að fara yfir orsök snjóflóðanna og aðgerðir vegna peirra, samkvæmt rannsókn Ásthildar Elvu. Engu að síður leiddi reynslan af snjóflóðunum af sér 
breytingar; skilvirkari og áhrifaríkari áætlanir Almannavarna, bætta upplýsingaferla, nýjar lagasetningar og einföldun á samvinnu milli stjórnunareininga.

Sömu raundæmi, auk raundæma um strand Víkartinds 1997 og Suðurlandsskjálftanna árið 2000, liggja til grundvallar í grein Ásthildar Elvu Bernharðsdóttur og Gunnars Helga Kristinssonar (2003) par sem reynt er að tengja kúltúrkenningu Mary Douglas, við áfallastjórnun. Niðurstöður benda til pess að

„einkenni áfallastjórnunar á Íslandi séu í góðu samræmi við tilgátur kúltúrkenningar. Jafnaðarhyggja er sterkasti menningarpátturinn á Íslandi og hún setur ríkan svip á áfallastjórnun. Pátttaka almennings er mikil í undirbúningi fyrir áföllin og í viðbrögðum par sem áhersla á valddreifingu helst að mestu óhögguð. Upplýsingastjórnun er veik og lærdómsferlið er valddreift. Pessi samandregna lýsing er sem sniðin að sjónarmiði jafnaðarhyggjunnar.“ (Ásthildur Elva Bernharðsdóttir og Gunnar Helgi Kristinsson, 2003, bls. 575).

Einnig er byggt á fjórum áðurnefndum raundæmum, auk raundæmis um yfirvofandi tímabundið bann Evrópusambandsins (e. european commission) á fiskimjöli í dýrafóðri árið 2000, í ritinu Small-State Crisis Management: The Icelandic Way (Ásthildur Elva Bernharðsdóttir og Svedin, 2004). Í ritinu er að finna afrakstur rannsóknasamstarfs íslenskra og sænskra fræðimanna par sem leitast er við að skilja eðli áfallastjórnunar í smáríki. Par sem niðurstöður voru ekki í samræmi við niðurstöður annarra fræðimanna um smáríki, var gerð tilraun til pess að skýra petta misræmi út frá sjónarhorni menningar, par sem gengið var út frá peirri niðurstöðu Ásthildar Elvu Bernharðsdóttur og Gunnars Helga Kristinssonar (2003) að sterkasta menningarlega einkenni áfallastjórnunar á Íslandi væri jafnaðarhyggja.

Í pví sambandi benda höfundar á dreifingu valds í almannavarnarkerfi landsins par sem ákvarðanir eru teknar á peim stöðum sem grípa parf til aðgerða og pátttaka mismunandi aðila er í samræmi við eðli krísunnar og par hafa sjálfboðaliðar stóru hlutverki að gegna. Á stigi undirbúnings og varna er áhersla jafnaðarhyggjunnar á pátttöku par sem frumkvæðið kemur beint frá almenningi en er stutt af ríkisstjórninni. Sjálfboðaliðar gegna undirbúningshlutverki að stóru leyti og ríkisstjórnin styður fyrirkomulagið með lagasetningu. Ákvarðanataka í krísu er valddreifð (e. decentralized) par sem verkaskipting og ábyrgð er óljós. Áhersla er á sjálfstjórn (e. autonomy) sveitastjórna, einstaklingsábyrgð og samtök sjálfboðaliða. Degar lítill sem enginn tími var til tímafrekrar hópvinnu var frumkvæði einstaklingsins áberandi í raundæmunum sem rannsökuð voru. Meðferð upplýsinga var hagnýt (e. pragmatic) og frekar óformleg, sem leiddi af sér óvissu en einnig sveigjanleika sem ýtti undir skapandi lausnir. Að auki skipti máli smæð pjóðarinnar og pétt tengslanet par sem pörf er fyrir alla og pátttaka allra er æskileg. Í lærdómsferlinu reyndist pátttaka veigameiri páttur en kerfisbundið mat á reynslu. Mikil áhersla virtist á sjálfstjórn í lærdómsferlinu, en raundæmið um yfirvofandi bann á fiskimjöli í dýrafóðri leiddi hins vegar í ljós að utanríkisráðuneytið beitti miðstýringu í meira mæli en sjá mátti í öðrum dæmum um áfallastjórnun á Íslandi. 


\section{STJÓRNMÁL \& \\ STJÓRNSÝSLA}

pegar leitað er í Skemmunni með leitarorðinu „áfallastjórnun“ koma upp 13 lokaritgerðir og ein ritrýnd grein. Í pessum verkum er ýmist fjallað um áfallastjórnun á beinan hátt eða hugtakið kemur fyrir í umfjöllun um önnur efni. Átta pessara verka eru BS ritgerðir sem skiptast pannig að fjórar fjalla um áfallastjórnun út frá viðskiptafræði, prjár út frá stjórnmálafræði og ein út frá menntavísindum. Af fimm MS ritgerðum fjalla fjórar um áfallastjórnun frá sjónarhóli viðskiptafræða og ein út frá stjórnmálafræði. Pess má einnig geta að pegar leitað er eftir orðinu „krísustjórnun“ koma upp tvö verk; ein BS ritgerð sem fjallar um krísustjórnun frá viðskiptafræðilegu sjónarhorni og ein MS ritgerð sem birtist einnig undir leitarorðinu ,áfallastjórnun“.

Viðfangsefni meistararitgerðanna eru áfallaáætlanir (Óskar Örn Árnason, 2009), stjórnun og upplýsingamiðlun á áfallatímum (Kristinn Jón Bjarnason, 2009), áfallastjórnun á opinberum vettvangi (Birna Ósk Hansdóttir, 2009), mannauðsstjórnun (Halla Valgerður Haraldsdóttir, 2010) og áhrifapættir við krísustjórnun fyrirtækja (Regína Ásdísardóttir, 2012). Eftirfarandi eru meginskilaboðin úr pessum verkum:

Fá eða um 30\% fyrirtækja á Íslandi gera áfallaáætlanir (Óskar Örn Árnason, 2009; Kristinn Jón Bjarnason, 2009) og hafa áfallateymi, fyrirfram tilgreindur talsmaður vegna áfalla er oftast framkvæmdastjóri, stjórnendur fyrirtækja telja pörf á að hafa áfallaáætlun og að auka purfi pekkingu um áfallastjórnun (Kristinn Jón Bjarnason, 2009). Einnig að viðbrögð íslenskra stjórnvalda við bankahruninu hafi að mörgu leyti rímað vel við viðmið áfallastjórnunar en að skort hafi á kerfisbundið upplýsingastreymi frá stjórnvöldum og að mikilvægi almannatengsla í viðbragðsferlinu hafi verið vanmetið (Birna Ósk Hansdóttir, 2009). Niðurstöður benda einnig til að mannauðsstjórar í íslenskum fyrirtækjum telji meiri pörf fyrir áfallastjórnun eftir efnahagshrunið (Halla Valgerður Haraldsdóttir, 2010) en ritgerð Evgenyiu Z. Demirevu (2011) gefur aftur á móti til kynna að vægi áfallastjórnunar og sálgæslu til starfsmanna hafi ekki aukist til muna sem viðfangsefni mannauðsstjóra í kjölfar bankahrunsins. Jafnframt má sjá dæmi um mikilvæga og innbyrðis tengda pætti krísustjórnunar; stjórnun og forysta, áætlanagerð og undirbúningur, menning, krísuteymi, samskipti og upplýsingagjöf, samstarf við hagsmunaaðila og lærdómur, par sem menning er hugsanlega lykilláttur (Regína Ásdísardóttir, 2012).

pegar staða íslenskra rannsókna á krísu- eða áfallastjórnun er dregin fram er ljóst að ekki hafa verið gerðar viðamiklar rannsóknir á krísustjórnun í fyrirtækjum. Áhersla hefur verið mun meiri á áfallastjórnun á vettvangi stjórnsýslunnar með áherslu á mikilvægi menningar.

\section{Atburđarásin hjá Icelandair 14. apríl til 18. maí, 2010}

Hér verður rakin atburðarás í kjölfar eldgossins í Eyjafjallajölki og viðbrögð stjórnenda Icelandair dagana 14. apríl til 18. maí 2010, eða frá upphafi gossins og pangað til truflunum á flugi vegna pess lauk.

Eldgosið olli víða truflun á flugumferð strax frá upphafi en alls röskuðust um fjögur púsund flugferðir 15. apríl í Norður Evrópu. Á Íslandi var flugi aflýst hluta úr degi sem hafði áhrif á um tvö púsund farpega Icelandair. Sérstakt krísuteymi Icelandair vegna eldgossins kom fyrst saman 15. apríl til pess að ákveða viðbrögð sem pað svo gerði 


\section{STJÓRNSÝSLA}

prisvar til fjórum sinnum á sólarhring meðan á krísunni stóð. Vegna sérstöðu krísunnar sem varðaði útfærslu á rekstri félagsins í ljósi aðstæðna en ekki flugöryggi eingöngu var ekki fyrirfram ákveðið hvaða starfsmenn kæmu að pessu sérstaka krísuteymi. Sérstakar viðbragðsáætlanir félagsins við krísuástandi ná ekki til utanaðkomandi aðstæðna eins og eldgosa og pað er ekki fyrirfram skilgreint hvernig bregðast skuli við eða hvaða starfsmenn skuli koma að málum. Yfirstjórn félagsins myndaði kjarnann í teyminu sem tók til við að bregðast við ástandinu. Segja má að eftirfarandi atburðir hafi einnig haft áhrif á viðbrögð Icelandair við krísunni sem hlaust af eldgosinu í Eyjafjallajökli. Í fyrsta lagi hafði eldgosið í Fimmvörðuhálsi skömmu áður sett starfsfólk í viðbragðsstöðu. Í öðru lagi höfðu stjórnendur fengið innsýn í möguleg áhrif eldgoss gegnum meistaraverkefni (Matthías Sveinbjörnsson, 2001), par sem unnið hafði verið spálíkan yfir líklega öskudreifingu ef upp kæmi eldgos í Mýrdalsjökli. Í priðja lagi hafði félagið reynslu af pví að glíma við erfiðleika, m.a. hafði pað gengið í gegnum rekstrarlegar prengingar eftir hrun bankakerfisins á Íslandi. Pessir tilteknu atburðir hafa mögulega haft pýðingu fyrir viðbragðsstöðu starfsfólks gagnvart pví ástandi sem skapaðist í rekstri Icelandair í kjölfar eldgossins í Eyjafjallajökli. Aðspurður um tilurð krísuteymisins vegna eldgossins í Eyjafjallajökli og mönnun pess segir Svali Björgvinsson, framkvæmdastjóri starfsmannasviðs Icelandair:

раð var gos parna á undan í Fimmvörðuhálsi [...] pað verður bara einhver atburðarás sem gerist [...] félagið var búið að fara í gegnum ansi miklar prengingar áður [...] pað kemur parna einhver sameiginlegur óvinur sem petta eldgos er, sem er ytri páttur, og pað myndast einhvers konar samstilltur hugur [...] við fengum svona smá brunaæfingu [...] svo kemur Eyjafjallajökull af fullum punga [...] pað var mjög merkilegt andrúmsloft sem myndaðist [...] fólk var boðið og búið að leggja sig fram [...] við getum ekki sagt að krísuhópurinn voru pessir tíu og svo einhverjir fyrir utan hann [...] petta var langt tímabil [...] yfirstjórnin var meira og minna inni í öllu [...] pað fjölgaði eða fækkaði í teyminu eftir pví sem purfa pótti (Svali Björgvinsson, munnleg heimild, 22. mars 2013).

Helsta hlutverk krísuteymisins var að fara yfir ösku- og veðurspár með starfsmönnum Veðurstofunnar og ISAVIA og ákveða viðbrögð í framhaldinu. Krísuteymið var í nánu samstarfi við flugumsjónarmiðstöðina í Keflavík og upplýsti starfsfólk Icelandair um breytingar á áætlanaflugi og leiðbeindi um æskileg viðbrögð, svo sem hvernig ætti að meðhöndla viðskiptavini sem áttu pantað flug. Alls voru um 130 innanhúss tölvupóstar sendir á tímabili gossins, um 100 fréttatilkynningar, 19 heimasíour félagsins voru uppfærðar nokkrum sinnum á dag á 11 tungumálum og skilaboð voru send til viðskiptavina í gegnum samfélagsmiðlana Facebook og Twitter (Icelandair, e. d.). 


\section{STJÓRNMÁL \& \\ STJÓRNSÝSLA}

Рað voru teknar á klukkutíma fresti mjög veigamiklar ákvarðanir. Leiðakerfið var í hönnun á hverjum degi. (Svali Björgvinsson, munnleg heimild, 22. mars 2013).

Meirihluti farpega Icelandair flýgur yfir Atlantshafið, milli Evrópu og Ameríku, með viðkomu á Íslandi. Icelandair varð að aflýsa mörgum flugferðum til Evrópulanda en gat haldið uppi Ameríkuflugi, vegna staðsetningar öskuskýsins. Vegna pessa myndaðist flöskuháls pví ferðamenn frá Ameríku komu áfram til Íslands, prátt fyrir gosið. Icelandair fékk 16. apríl leyfi fyrir premur aukaflugum til Glasgow til pess að flytja farpega áfram til meginlands Evrópu og ná í strandaglópa. Dann 17. apríl var öllu flugi frá Íslandi til Evrópu aflýst og tilkynnt var að öllu flugi yrði einnig aflýst næsta dag. Nýtt tækifæri gafst hins vegar til pess að létta á flöskuhálsinum á Íslandi pegar Icelandair fékk leyfi 18. apríl til pess að fljúga til Drándheims í Noregi. Y fir 900 farpegar flugu pangað og komust pannig til meginlands Evrópu, prátt fyrir að öđru flugi væri aflýst til Evrópu frá Íslandi (Icelandair, e.d.). Á meðan önnur flugfélög aflýstu flugum sínum pegar flugvellir eða flugleiðir voru lokaðar, flaug Icelandair til staða sem ekki voru venjulegir áfangastaðir félagsins. Stjórnandi A lýsti viðbrögðum pannig:

Við vorum að gera pað sem aðrir voru ekki að gera vegna pess að við hugsuðum aðeins út fyrir boxið. [...] Fyrstu viðbrögðin hjá mörgum voru pau að petta væri ekki hægt og best væri að loka. Hér ríkir önnur hugsun, nokkurs konar flugmannahugsun sem felur í sér; ég parf að fara eitthvert og hvernig kemst ég pangað? Рað myndaðist viss vertíðarstemmning í fyrirtækinu og allir vildu leggja mikið á sig til að láta hlutina ganga upp (Icelandair, e.d.).

Stjórnendur Icelandair Group og stjórnendur dótturfélaga, par með talið Icelandair, héldu fund pann 18. apríl par sem ræddar voru afleiðingar gossins og var áhersla lögð á nauðsyn pess að íslensk stjórnvöld tækju höndum saman við hagsmunaðila ferðapjónustunnar til pess að kynna Ísland og stöðuna á Íslandi fyrir útlendingum, en nokkuð hafði borið á neikvæðri og misvísandi umfjöllun í erlendum fjölmiðlum. Daginn eftir kynnti Guðjón Arngrímsson, upplýsingafulltrúi Icelandair, hugmyndina á fundi í utanríkisráðuneytinu. Icelandair var pá falið að próa hugmyndina áfram og koma með frekari tillögur tveimur dögum seinna til iðnaðarráðherra. Petta lagði grunn að kynningar- og markaðsherferðinni Inspired by Iceland (Icelandair, e.d.). Fulltrúar Icelandair lýstu pví einnig yfir að peir væru tilbúnir til pess að veita í verkefnið fé umfram fjárhagsáætlun peirra til markaðsstarfa. Framlag Icelandair til átaksins var 125 milljónir af 700 milljóna króna heildarframlagi pátttökuaðila og sat Guðjón Arngrímsson í framkvæmdanefnd Inspired by Iceland fyrir hönd Icelandair (Inga Hlín Pálsdóttir og Einar Karl Haraldsson, 2011).

Pann 19. apríl tilkynnti Icelandair Group að áætlað tap félagsins vegna truflanna á flugumferð væri um 100 milljónir króna á dag. Áfram hélst Ameríkuflug á áætlun og 
fraktflugi milli Íslands og Evrópu var haldið uppi eins og hægt var (Icelandair Group, 2010). Aukaflug voru áfram flogin en hluta áætlaðra flugferða var aflýst („Icelandair flýgur", 2010).

Dagana 15. til 20. apríl flaug Icelandair einungis 56\% af áætluðum flugferðum sem hafði áhrif á um 20 púsund farpega félagsins. Pann 20. apríl opnaði Icelandair Group upplýsingasíðu um eldgosið í Eyjafjallajökli til pess að leggja áherslu á að lífið á Íslandi gengi prátt fyrir allt sinn vanagang. Einnig voru upplýsingar veittar um ferðatilhögun, tímasetningar flugferða og um eldsumbrotin í Eyjafjallajökli („Upplýsingasíða um eldgosid“, 2010).

Aukaflugin reyndust félaginu kostnaðarsöm, par sem vélarnar voru oft og tíðum hálftómar eða tómar aðra leiðina. Engu að síður ákváðu stjórnendur Icelandair að halda aukafluginu áfram, ekki einungis til pess að losa um fyrrgreindan flöskuháls, heldur töldu peir einnig mikilvægt að halda vélunum á lofti yfir Atlantshafinu svo viðskiptavinir héldu áfram að bóka en ekki hverfa á braut. Ljóst pótti að enginn myndi bóka flug með flugfélagi sem væri ekki að fljúga (Icelandair, e.d.).

Við mátum pað pannig að pað væri dýrmætt fyrir félagið að halda uppi öllu mögulegu flugi á milli Evrópu og Ameríku. Með pví móti kæmum við í veg fyrir að bókanir hjá félaginu myndu stoppa. Fljótlega eftir að gosið hófst dró verulega út bókunum til landsins en ekki úr bókunum yfir Atlantshafið (Stjórnandi B, Icelandair, e.d.).

pann 21. apríl opnuðust flugleiðir, Icelandair flaug pví til flestra áfangastaða í Evrópu og Ameríkuflug var enn á áætlun. Spár bentu hinsvegar til pess að mögulega pyrfti að loka Keflavíkurflugvelli tveimur dögum seinna. Krísuteymið hafði á reglulegum fundum sínum gert ráð fyrir pessum möguleika og taldi tvo kosti koma til greina; að aflýsa öllu flugi eða færa flugmiðstöð Keflavíkurflugvallar á annan flugvöll, annaðhvort til Oslo eða Glasgow. Niðurstaðan varð sú að hefja pegar í stað undirbúning að flutningi flugmiðstöðvarinnar til Glasgow, prátt fyrir að endanleg ákvörðun lægi ekki fyrir (Icelandair, e.d.).

Flestir flugvellir Evrópu voru opnir 22. apríl og pví loks hægt að fljúga á alla áfangastaði álfunnar. Flöskuhálsinn var nærri horfinn og útlit var fyrir eðlilega flugumferð á ný (Icelandair, e.d.). Hinsvegar staðfestu spár að nauðsynlegt yrði að loka Keflavíkurflugvelli næsta dag. Starfsfólki var tilkynnt um pað og lokaákvörðun var tekin um að færa flugmiðstöðina til Glasgow. Á pessum tímapunkti hafði Icelandair aflýst um 100 flugferðum og tap var áætlað um 700 milljónir („Dúsundir strandaglópa“, 2010). Ljóst var að flutningurinn yrði dýr og flókinn en mat stjórnenda var að hann myndi svara kostnaði til lengri tíma litið.

[‥] Ég var alltaf ósammála pví að horfa of mikið á pær tölur enda taldi ég að pað væri mikilvægara að halda starfseminni gangandi. Kostnaðurinn [...] var lítill miðað við pær tekjur sem kynnu að tapast ef við hættum að fljúga (Stjórnandi C, Icelandair, e.d.a).

Einnig var ákveðið að nýta flugvöllinn á Akureyri sem flugmiðstöð, sem ekki var síður dýr og flókin aðgerð. Icelandair reiddi sig á samstarf við hagsmunaaðila svo flutning- 


\section{STJÓRNMÁL \& \\ STJÓRNSÝSLA}

urinn yrði mögulegur með skömmum fyrirvara og flugleiðum par með haldið opnum (Icelandair, e.d.). Dann 23. apríl hófst reglulegt flug Icelandair milli Evrópu og Ameríku í gegnum Glasgow en nú voru allir flugvellir opnir nema í Keflavík. Annríki á Akureyrarflugvelli hafði aldrei áður verið eins mikið og nú, pegar miðstöð millilandaflugs hafði verið flutt pangað. Að sögn Hjördísar Guðmundsdóttur, upplýsingafulltrúa ISAVIA, gekk aðgerðaráætlun sem sett hafði verið í gang vel. Gott samstarf ríkti á milli embætta tollstjóra og lögreglu, auk slökkviliðsins á Akureyri sem bætti við tækjum og mannskap á vellinum (,Aðeins Egilsstaðavöllur“", 2010).

Pann 27. apríl var orðið ljóst að bókanir hjá Icelandair höfðu dregist saman um 75\% miðað við eðlilegar aðstæður á pessum árstíma („,75\% samdráttur“, 2010). Bæði Keflavíkur- og Akureyrarflugvöllur voru lokaðir og óvíst var hvenær peir gætu opnast að nýju. Að venju fundaði krísuteymi Icelandair um morguninn og ákvað eftir miklar umræður og skoðanaskipti, að flytja tengimiðstöðina aftur frá Glasgow til Keflavíkur. Leiðarkerfi Icelandair í Keflavík varð virkt sólarhring seinna og flug var að mestu komið á áætlun pann 28. apríl og næstu átta til níu daga (Icelandair, e.d.).

Pann 4. maí undirrituðu yfirvöld og aðilar ferðapjónustunnar, p.m.t. Icelandair, samning um pátttöku í Inspired by Iceland. Dagana 7.-8. maí lokaðist Keflavíkurflugvöllur aftur og flugmiðstöðin var að nýju flutt til Glasgow og Akureyrar. Dagana 10.-13. maí opnaðist Keflavíkurflugvöllur og tengimiðstöðin var flutt pangað að nýju. Flug var á áxtlun dagana 10.-12. maí. Pann 14. maí lokuðust vélar inni í Keflavík og öllu flugi, eða um 32 ferðum var aflýst. Dagana 15.-18. maí var losað um flöskuháls með aukaflugi en flug komst að mestu leyti í eðlilegt horf pann 18. og ekki urðu fleiri tafir á flugi hjá Icelandair vegna eldgossins í Eyjafjallajökli (Icelandair, e.d.).

\section{Niðurstöður og umræða}

Hér að framan hefur verið lýst bæði hinu fræðilega sjónarhorni rannsóknarinnar og raundæminu sem rannsakað er. Til að draga saman niðurstöður á sem skýrastan hátt verður unnið út frá rannsóknarspurningunum sem leitað er svara við.

\subsection{Að hvaða marki var Icelandair að glíma við krísu?}

Eldgosið í Eyjafjallajökli raskaði starfsemi Icelandair pannig að flugleiðir lokuðust sem leiddi til peirrar miklu áskorunar fyrir stjórnendur að halda starfseminni gangandi og tjóni í lágmarki. Sé litið til fræðanna og peirra skilgreininga á krísu og krísustjórnun sem horft er til í pessu verkefni má sjá samsvörun á milli ástandsins sem skapaðist hjá Icelandair í kjölfar gossins og krísuástands.

Náttúruhamfarir eru einn orsakavaldur krísuástands. Enginn gat með vissu vitað að eldgos yrði á tilteknum tíma í Eyjafjallajökli. Ekki heldur af hvaða stærðargráðu gosið yrði og hver áhrif yrðu af öskudreifingunni á flugáætlanir og rekstur Icelandair. Aldrei áður hafði flug raskast með pessum hætti. Krísan sem um ræðir í raundæmi greinarinnar samræmist pví vel peim skilningi sem fræðimenn hafa lagt í hugtakið krísu sem er að krísa sé fyrirvaralaus, ópekkt og ósennilegt ástand sem hefur gífurleg áhrif (Pearson og Clair, 1998; Reilly, 1987; Rosenthal, Boin og Comfort, 2001; Perrow, 1984, Carter 1991). 


\section{STJÓRNSÝSLA}

Eldgosið í Eyjafjallajökli var hamfaragos (e. cataclysmic) og öskuskýið náði um og yfir 10 km hæð. Dreifing öskuskýsins olli pví að lokanir flugsvæða í Evrópu urðu pær mestu frá seinni heimstyrjöld (Tamagno, 2010) og pað raskaði verulega starfsemi Icelandair. Eldgosið olli krísuástandi sem krafðist skjótra viðbragða, skapaði óöryggi og streitu og varð til pess að vel var fylgst með viðbrögðum Icelandair par sem margir áttu hagsmuna að gæta.

pegar rýnt er í raundæmið um Icelandair með hliðsjón af kenningum um krísustjórnun parf að taka mið af pví að horft er á tímabilið frá pví að gosið hófst par til pví lauk. Á pví tímaskeiði má sjá að aðgerðir fyrirtækisins eiga mest við pann pátt í krísustjórnunarlíkani Ritchies (2004) sem lýtur að skrefi prjú og fjögur í viðbrögðum við krísum. Varðandi undirbúning fyrir krísuástand af pví tagi sem hér er til umfjöllunar segir í skýrslu:

рó svo að krísunefndin æfi reglulega viðbrögð við hinum ýmsu atburðum sem kunna að koma upp á við rekstur flugfélaga, pá var hún ekki búin að samhæfa eða æfa aðgerðir fyrir pessa baráttu. Sú undirbúningsvinna sem pegar hafði farið fram vegna hættunnar á eldgosi hafði að mestu verið unnin hjá einstaka deildum en ekki innan krísunefndarinnar (Icelandair, e.d.).

Hér kemur fram að krísan sem við var að glíma var ekki af pví tagi sem viðbragðsáætlanir flugfélagsins taka til. Krísan sem hér var um að ræða snerist ekki um flugatvik eða flugöryggi. Slíku var aldrei teflt í tvísýnu, enda flogið framhjá öskunni. Krísan varðaði rekstur félagsins og aðspurður sagði stjórnandi hjá Icelandair að pað væri ekki til krísuáætlun fyrir svona aðstæður en að pað hefði ótvírætt verið litið á ástandið sem krísu. Að mati stjórnenda var reksturinn í húfi. Undirstaðan í rekstrinum er leiðarkerfið og pví má líkja ástandinu hjá Icelandair við undirstöðukrísu (Gundell, 2005). Trúverðugleiki félagsins snerist um að halda leiðakerfinu gangandi og til að gera pað mögulegt var gripið til pess að færa tengimiðstöð flugsins til Glasgow. Segja má að sú ákvörðun hafi verið á vissan hátt sjálfsprottin í krísustjórnunarferlinu og hún var möguleg vegna pess að félagið bjó yfir víðtækri pekkingu og starfsfólki sem hefur mikla og langa reynslu í störfum sínum fyrir félagið (Svali Björgvinsson, munnleg heimild, 22. mars 2013).

Leiðakerfið er algjör burðarbiti. [...] Рað að við gátum haldið uppi leiðakerfinu er sigur fyrir félagið. [...] Burðarbitinn í stefnunni hélt. [...] Раð var markmiðið í gegnum petta allt. (Svali Björgvinsson, munnleg heimild, 22. mars 2013).

Ofangreint staðfestir að Icelandair og stjórnendur félagsins voru að glíma við krísu sem ógnaði rekstri félagsins og möguleikum pess til að fylgja eftir stefnu í starfseminni. 
Gefa viðbrögð við eldgosi innsýn í krísustjórnun.

Regína Ásdísardóttir og Runólfur Smári

Steinpórsson

\section{STJÓRNMÁL \& \\ STJÓRNSÝSLA}

\subsection{Hvernig voru stjórnendur og starfsfólk Icelandair að bregðast við?}

Hjá Icelandair er mjög skýrt verklag og skilgreind hlutverk hjá ákveðinni krísunefnd ef upp koma krísur sem skilgreina má sem flugatvik (t.d. flugslys). Krísan sem kom upp í kjölfar eldgossins flokkaðist ekki sem pess konar flugatvik og pví var sú krísunefnd ekki virkjuð. Viðbrögðin voru að lykilstjórnendur Icelandair mynduðu sérstakt krísuteymi til pess að bregðast við aðstæðum. Баð „komu fleiri og aðrir að krísustjórnuninni“ en peir sem skipa hina föstu krísunefnd. Framkvæmdastjórinn fór fyrir teyminu en aðrir í teyminu voru líka í leiðandi hlutverkum við daglega stjórnun pess og leiddu umræður á fundum (Guðjón Arngrímsson, munnleg heimild, 22. ágúst 2012). Framkvæmdastjóri Icelandair hafði lokaorðið í ákvarðanatöku teymisins en áhersla var lögð á að hlusta á sjónarmið og byggja á fagpekkingu aðila og starfshópa innan félagsins. Opin samskipti voru höfð аð leiðarljósi, pannig að umræður og skoðanaskipti fengu rými á fundum (Icelandair, e.d.).

Með reglulegum fundum, eftir að ösku- og veðurspár bárust, stuðlaði krísuteymið að skjótri ákvarðanatöku og framkvæmd aðgerða í framhaldinu. Á fundum krísuteymisins voru rædd flugrekstrarmál, öryggismál, tæknileg úrvinnsla við framkvæmd flugs, markaðsmál, starfsmannamál og samskipti við farpega og fjölmiðla. Mikið álag var á krísuteyminu og preyta sagði til sín pegar menn stóðu langar vaktir undir mikilli tímapressu. prátt fyrir að ákveðnir ferlar væru til hjá Icelandair um pað hvernig ætti að bregðast við í óhefðbundum aðstæðum eða áföllum, hafði krísuteymið ekki samhæft eða æft aðgerðir sérstaklega til pess að bregðast við eldgosi. Starfshættir mynduðust pó fljótt á pann veg að fyrst var möguleikum um viðbrögð velt upp, síðan voru ákvarðanir teknar um viðbrögð og svo kom pað í hlut hvers og eins í teyminu að koma ákvörðunum í framkvæmd ásamt öðrum starfsmönnum Icelandair (Icelandair, e.d.). Einna veigamestu ákvarðanir krísuteymisins snéru að tilfærslum flugmiðstöðvarinnar milli Keflavíkur, Glasgow og Akureyrar, prátt fyrir aukinn kostnað og aukið vinnuálag.

Starfsmenn voru reglulega upplýstir um gang mála og til marks um pað voru sendir um 130 leiðbeinandi tölvupóstar innanhúss á tímabili eldgossins. Icelandair sendi frá sér um 100 fréttatilkynningar og 19 heimasíður félagsins voru uppfærðar nokkrum sinnum á dag á 11 tungumálum, ásamt pví sem samfélagsmiðlarnir Facebook og Twitter voru nýttir til samskipta við viðskiptavini. Sérstök upplýsingasíða var einnig opnuð til pess að miðla upplýsingum varðandi flug og staðreyndum um ástandið á Íslandi. Samskipti og upplýsingagjöf voru liður í pví að eyða óvissu, koma í veg fyrir misskilning, greiða fyrir ákvarðanatöku og stuðla að jákvæðri ímynd Íslands.

Sjá má á atburðarásinni að Icelandair lagði áherslu á samstarf við helstu hagsmunaaðila. Mikið reyndi á sveigjanleika starfsfólks, sömuleiðis framlag og samstarfsvilja stéttarfélaga í kjölfar aukins álags og erfiðra starfsskilyrða. Flugmálayfirvöld, Tollstjóri, lögregla og slökkvilið voru nauðsynlegir samstarfsaðilar sem gerðu Icelandair kleift að flytja flugmiðstöð sína til Glasgow og Akureyrar. Icelandair átti einnig í virkum samskiptum við stjórnvöld og hagsmunaaðila ferðapjónustunnar m.a. varðandi markaðs- og kynningarátakið Inspired by Iceland. 


\section{STJÓRNSÝSLA}

\subsection{Hvađa lærdóm má draga af reynslu Icelandair um krísustjórnun?}

Icelandair tókst að halda uppi um $80 \%$ starfseminnar meðan á gosinu stóð og mikil stemmning og samstaða myndaðist hjá starfsfólki til að gera petta mögulegt. Fyrirtækið brá út af áætlunum og venju. Рað bætti við flugleiðum pegar færi gafst og flutti flugmiðstöð sína frá Keflavík til Glasgow og Akureyrar í tvígang. Pannig tókst félaginu að verja stöðu sína og halda uppi pjónustu. Í pessum aðgerðum naut félagið mikils stuðnings frá starfsfólki, stjórnvöldum og öðrum hagsmunaaðilum.

Starfsemi flugfélags einkennist jafnan af mikilli fyrirhyggju. Stór hluti starfseminnar er afar formfastur. Mikið er um skilgreinda ferla og áætlanir. Begar óvæntur og bráður atburður verður til pess að raska pví umhverfi er áhugavert að skoða hvernig brugðist er við í pess háttar skipulagsheild. Skyndilega er starfsfólki kippt út úr pekktum aðstæðum og kastað út í óvissuna. Tímapressan er gífurleg og afkoma félagsins liggur undir. Hvernig er brugðist við og hvernig eru ákvarðanir teknar undir slíkum kringumstæðum? Hvaða atriði og pættir birtast sem mikilvægir í slíku ákvarðanaferli? Er krísustjórnunin í takti við fyrirliggjandi viðbragðsáætlanir eða eru viðbrögðin sjálfsprottin hjá krísuteyminu á peim stað og peirri stund sem um ræðir? Hvernig var áætlunum fylgt eftir í raun og veru, pegar á hólminn var komið? Hvernig nýttust fyrirliggjandi áætlanir?

Dæmið um Icelandair sýnir að viðbrögðin við krísunni sem hamfaragosið í Eyjafjallajökli var kveikjan að voru byggð á pekkingu og reynslu starfsmanna. Framvinda athafna var meira sjálfsprottin en fyrirfram skipulögð. Krísan sem um ræðir er tilkomin vegna utanaðkomandi aðstæðna, náttúruhamfara. Fram kemur að félagið hafði velt upp peim möguleika að svona ástand kæmi upp en pað hafði ekki átt sér stað kerfisbundinn undirbúningur eða próun á sérstökum forvörnum hjá krísunefnd félagsins. Sett í samhengi við líkan Ritchies (2004) og pau skref sem jafnan eru í krísustjórnun (Pearson og Mitroff, 1993; Heath, 1998) pá má sjá að aðgerðir krísuteymisins hjá Icelandair eiga sér ákveðna samsvörun við pekkt skref 1 krísustjórnun, p.e. undirbúningi og viðbrögðum. Varðandi undirbúning fékk félagið viðvörun með gosinu í Fimmvörðuhálsi, kynningu á áhrifum öskudreifingar og pað bjó yfir reynslu af erfiðleikum, viðbrögð voru afgerandi með sérstöku krísuteymi og vöktun meðan á ástandinu stóð. Dað er hins vegar ekki að sjá í pessu dæmi mikla samsvörun við stefnumiðaða nálgun krísustjórnunar (Ritchie, 2004) vegna pess hversu mikið ferlið mótaðist af reynslu starfsfólks og sjálfsprottnum athöfnum meðan á krísunni stóð.

Raundæmið sem rakið hefur verið varpar ljósi á ýmsa áhugaverða pætti í krísustjórnun fyrirtækja. Dæmið sýnir hvernig fyrirtæki er að takast á við tímabundið krísuástand vegna náttúruhamfara. Vandamálið tengist ekki fyrirtækinu beint en ógnar rekstri pess. par sem vandamálið er sérstakt og knýjandi eru viðbrögðin og atburðarás athafnanna á margan hátt sjálfsprottin. Við sjáum dæmi um sjálfsprottna skipulagningu par sem reynsla og menning á vinnustað er í aðalhlutverki. Um pessa hlið krísustjórnunar virðist ekki fjallað að neinu marki í peim krísustjórnunarfræðum sem rakin voru í fræðilega kaflanum og pví er petta dæmi mikilvægt. Reynsla Icelandair bendir til pess að sú mikla pekking og reynsla sem er til staðar í fyrirtækinu hafi verið lykillinn að hinni árangursríku krísustjórnun félagsins á tímabilinu sem gosið stóð. 


\section{STJÓRNMÁL \& \\ STJÓRNSÝSLA}

Ég held að pað sem skipti sköpum í pessu er að pað er rúmlega 20 ára meðalstarfsaldur hjá félaginu. Sú pekking sem býr í fólki um pað hvernig ætti að færa „operationina“ bæði til Akureyrar og til Glasgow var til staðar. [...] Petta fólk vissi nákvæmlega pað sem purfti að gera til að færa petta. [...] Sú reynsla og pekking var feykilega dýrmæt (Svali Björgvinsson, munnleg heimild, 22. mars 2013).

Reynsla Icelandair í pessu dæmi gefur til kynna að pegar leysa parf úr erfiðum viðfangsefnum við knýjandi aðstæður er upplýsingagjöf, hröð ákvarðanataka, gott samstarf við hagsmunaaðila, samstaða og fórnfýsi starfsmanna afar mikilvæg atriði. Einnig sýnir petta dæmi að pegar engin áætlun er fyrirliggjandi um viðbrögð við tilteknu ástandi pá vindur ákvarðanatöku og skipulagningu fram í sjálfsprottnu ferli. Við pær aðstæður skiptir uppsöfnuð reynsla og kunnátta í félaginu og hjá starfsfólki pess gríðarlega miklu máli.

Eins og skilgreint var í upphafi pá er hér um könnunarrannsókn að ræða sem hefur раð аð markmiði að draga fram yfirsýn og innsýn í pað viðfangsefni sem er til skoðunar. Rannsóknin hefur sýnt að pað má lýsa ástandinu sem Icelandair var að bregðast við á meðan á gosinu stóð sem krísu og raundæmið gefur innsýn í pað hvernig fyrirtæki er að bregðast við slíku ástandi. Pegar sú atburðarás er sett í samhengi við fyrirliggjandi pekkingu um krísustjórnun kemur í ljós að par er um ákveðna samsvörun að ræða en líka að atburðarásin mótaðist af reynslu starfsmanna og var sjálfsprottin á margan hátt. Par sem lítið virðist fjallað um pann pátt í krísustjórnunarfræðum má segja að reynsla Icelandair og árangur gefi tilefni til pess að sú hlið krísustjórnunar verði rannsökuð frekar.

\section{Frekari rannsóknir og næstu skref}

Dessi rannsókn á krísustjórnun hefur leitt í ljós að fræðigreinin er talin ung og hún er í próun. Fyrirliggjandi kenningar um krísustjórnun virðast að miklu leyti sækja grundvöll sinn í rökræna nálgun á framsetningu stjórnunarkenninga. Fram kemur að fleiri nálganir séu viðhafðar einnig. Á Íslandi hafa ekki verið stundaðar miklar rannsóknir á krísustjórnun. Veigamesta framlagið er að finna í rannsóknum sem beinast að opinberum aðilum. Lítið er um rannsóknir á krísustjórnun fyrirtækja.

Бað er óumdeilt að pað skiptir afar miklu máli að fyrirtæki geti sem best ráðið við fyrirvaralausar, erfiðar og knýjandi aðstæður. Pekking stjórnenda á krísustjórnun getur skipt sköpum um lífvænleika fyrirtækis ef og pegar krísa skellur á. Pá er mikilvægt að skilja hvernig ýta megi undir árangursríka krísustjórnun og hvaða pættir eru mikilvægir í pví sambandi. Fyrirliggjandi kenningar leggja áherslu á undirbúning og forvirkar aðgerðir en dæmið um viðbrögð Icelandair við gosinu í Eyjafjallajökli undirstrikar að sjálfsprottnar aðgerðir geti haft úrslitapýðingu.

Samanburður á pví sem raundæmið hefur að geyma um pessa tilteknu atburðarás krísustjórnunar við pað sem finna má í fræðunum um krísustjórnun gefur líka tilefni til frekari rannsókna og rannsóknarspurninga. Spyrja má um pýðingu forystu í ferlinu. Einnig um menningu fyrirtækja og peirra pjóða sem fyrirtækin eiga uppruna sinn í. Ennfremur væri áhugavert að fylgja dæminu eftir og kortleggja pað hvernig fyrirtæki 


\section{STJÓRNSÝSLA}

eins og Icelandair er að draga lærdóm af pessari atburðarás og byggja á peim skilningi sem verður til í tengslum við undirbúning og forvarnir gegn mögulegum krísum í framtíðinni.

Krísunni hjá Icelandair var sannarlega mætt með opnum huga og skapandi hugsun um leið og fyllsta öryggis var gætt. Dæmið er einnig til vitnis um vilja og samstöðu starfsfólks til að ráðast í óvenjulegar og frumlegar aðgerðir og pannig koma í veg fyrir tjón og halda upp pjónustustigi. Frekari rannsóknir á raundæmum eins og pessu gætu opnað fyrir skilning á mikilvægi pess að skapa grunn að sjálfsprottnu ferli og framvindu ábyrgrar krísustjórnunar. Slíkur skilningur væri framlag til bæði fræðasamfélagsins og til peirra sem purfa að bera ábyrgð og taka ákvarðanir við erfiðar og knýjandi aðstæður.

\section{Heimildir}

75\% samdráttur í bókunum. (27. apríl, 2010). Mbl.is. Sótt í mars 2012 af: http://www.mbl.is/frettir/ innlent/2010/04/27/75_prosent_samdrattur_i_bokunum/

Aðeins Egilsstaðavöllur opinn. (24. apríl, 2010). Mbl.is. Sótt í mars 2012 af: http:/ /www.mbl.is/frettir/ innlent/2010/04/24/adeins_egilsstadavollur_opinn/

Alvarez, J. F. A., Pustina, A. og Hällgren, M. (2011). Escalating commitment in the death zone. New insights from the 1996 Mount Everest disaster. International Journal of Project Management, 29, 971-985.

Anna Anita Jónsdóttir. (2011). Impact of Eyjafjallajökull on tourism and international flights. Háskóli Íslands. B. Sc. ritgerð.

Argenti, P. A. og Forman, J. (2002). The power of corporate communication: Crafting the voice and image of your business. New York: McGraw-Hill.

Armstrong, E. K. (2008). Tourism destination recovery after the 2003 Canberra fires. Háskólinn í Canberra, Ástralíu. Óbirt doktorsritgerð.

Arna H. Jónsdóttir. (2001). Starfsánægja og stjórnun í leikskólum. Uppeldi og menntun,10, 45-89.

Ásthildur Elva Bernharðsdóttir. (2001). Learning from past experiences: The 1995 avalanches in Iceland. Stockholm: Försvarshögskolan.

Ásthildur Elva Bernharðsdóttir og Gunnar Helgi Kristinsson (2003). Kúltúrkenning um áfallastjórnun. Í Friðrik H. Jónsson (ritsj.), Rannsóknir i félagsvísindum IV, Félagsvísindadeild, erindi flutt á ráostefnu ífebríar 2003, 559-579.

Ásthildur Elva Bernharðsdóttir og Svedin, L. (ritstjórar) (2004). Small-State Crisis Management: The Icelandic Way. Stokkhólmur: Crisis Management Eourope Research Program.

Barton, L. (1993). Crisis in Organizations: Managing and Communicating in the Heat of Chaos. Cincinnati: South-Western Publishing í Zhong og Low (2009).

Birna Ósk Hansdóttir. (2009). Áfallastjórnun í opinberri stjórnsýslu: Íslenska bankahrunið 2008 og pýska dvalarleyfismálið 2005. Háskóli Íslands. MS ritgerð.

Boin, A. og Lagadec, P. (2000). Preparing for the future: critical challenges in crisis management. Journal of Contingencies and Crisis Management, 8(4), 185-191 í Paraskevas (2006).

Boin, A. og t’Hart, P. (2003). Public leadership on times of crisis: Mission Impossible? Public Administration Review, 63(5), 544-553.

Bouty, I., Godé, C., Drucker-Godard, C., Liévre, P., Nizet, J. og Pichault, F. (2012). Coordination practices in extreme situations. European Management Journal, article in press.

Bowden, S. (2011). Aftershock: Business relocation decisions in the wake of the February 2011 Christchurch earthquake. Journal of Management and Organization, 17, 857-863.

Bromiley, P. og Marcus, A. (1989). The deterrent to dubious corporate behavior: Profitability, probability and safety recalls. Strategic Management Journal, 10(3), 233-250.

Bryman, A. (2008). Social Research Methods. Oxford: Oxford University Press. 


\section{STJÓRNMÁL $\&$ STJÓRNSÝSLA}

Carter, W. N. (1991). Disaster management: A disaster manager's handbook. Manila: Asian Developement Bank.

Cloudman, R. og Hallahan, K. (2006). Crisis communications preparedness among U.S. organizations: Activities and assessments by public relations practitioners. Public Relations Review, 32(4), 367-376.

Coombs, W. T. (2007). Ongoing Crisis Communication, Planning, Managing and Responding, önnur útgáfa. Newbury Park: Sage Publications í Zhong og Low (2009).

DeChurch, L. A., Burke, C. S., Shuffler, M. L., Lyons, R., Doty, D. og Salas, E. (2011). A histometric analysis of leadership in mission critical multiteam environments. The Leadership Quarterly, 22, 152-169.

Dul, J. og Hak, T. (2008). Case Study Methodology in Business Research. Oxford: Butterworth-Heinemann.

Duncan, W. J., Yeager, V. A., Rucks, A. C. og Ginter, P. M. (2011). Surviving organizational disasters. Business Horizons, 54, 135-142.

Elsubbaugh, S., Fildes R. og Rose, M. B. (2004). Preparation for crisis managment: A proposed model and empirical evidence. Journal of Contingencies and Crisis management, 12(3), 112-127.

Eurocontrol. (2010). Ash-cloud of April and May 2010; Impact on Air Traffic. Í STATFOR, European Organization for Safety of Air Navigation (doc 394). Sótt 5. febrúar 2012 af: http://www.eurocontrol.int/sites/default/files/content/documents/official-documents/facts-and-figures/statfor/ ash-impact-air-traffic-2010.pdf

Evgenyia Z. Demireva. (2012). Hæfni íslenskra mannauðsstjóra. “Allt í senn sálfræðingur, lögfræðingur og fjármálastjóri." Háskóli Íslands. MS ritgerð.

Faulkner, B. (2001). Towards a framework for tourism disaster management. Tourism Management, 22(2), 135-147.

Fink, S. (1986). Crisis management. New York: American Association of Management.Francisco, CA: Jossey-Bass Publishers.

Fink, S., Beak, J. og Taddeo, K. (1971). Organizational crisis and change. Journal of Applied Behavioral Science, 7(1), 15-37.

Fisher, K., Hutchings, K. og Sarros, J. C. (2010). The "Bright" and "Shadow" Aspects of in Extremis Leadership. Military Psychology, 22 (1), 89-116.

Ghauri, P. og Grønhaug, K. (2002). Research Methods in Business Studies. Essex: Pearson Education Limited.

Guðrún Stefánsdóttir. (2000). Boðskipti mikið fatlaðra barna. Uppeldi og menntun, 1(9), 113-142.

Gundel, S. (2005). Towards a New Typology of Crises. Journal of contingencies and crisis management, 13(3), 106-115.

Grendstad, G., Jensen, L. Kristinsson, G. H., Sjöberg, L. og Sundback, S. (1999). Nordic cultures: Measurement, consequences and comparisons. Bergen: LOS-sentret.

Halla Valgerður Haraldsdóttir. (2010). Áhrif efnahagshrunsins á viðfangsefni mannauðsstjóra og líðan peirra í starfi. Háskóli Íslands. MS ritgerð.

Hannah, S. T., Uhl-Bien, M., Avolio, B. J. og Cavaretta, F. L. (2009). A framework for examining leadership in extreme contexts. The Leadership Quarterly, 20, 897-919.

Heath, R. (1998). Crisis management for managers and executives. London: Financial Times Management.

Hutchins, H. M. og Wang, J. (2008). Organizational Crisis Management and Human Resource Development: A Review of the Literature and Implications to HRD Research and Practice. Advances in Developing Human Resources, 10(3), 310-330.

IATA. (2010). IATA Economic Briefing May 2010. The Impact of Eyjafjallajokull's volcanic ash plume. IATA Economics. Sótt 17. mars 2012 af: http://www.iata.org/whatwedo/Documents/economics/ Volcanic-Ash-Plume-May2010.pdf

Icelandair flýgur til Gautaborgar. (19. apríl, 2010). mbl.is. Sótt í febrúar 2012 af: http://www.mbl.is/ frettir/innlent/2010/04/19/icelandair_flygur_til_gautaborgar/

Icelandair Group. (19. apríl, 2010). Icelandair Group hf. Company Announcement. Effects of Eruption and Volcanic Ash on Icelandair Group. Sótt í febrúar 2012 af: https:/ /newsclient.omxgroup.com/ cdsPublic/viewDisclosure.action?disclosureId=397020\&messageId $=477620$ 
Icelandair. (e.d.). Flogið framhjá öskunni. Óútgefin skýrsla.

ICM, Institute for Crisis Management. ( 8. ágúst, 1996). Debunking the stereotypes of crisis management: The nature of Business Crises in the 1990‘s. Sótt 2. júní 2012 af: http://www.crisisexperts. com/debunking_main.htm

ICM, Institute for Crisis Management. (e.d.). Crisis definitions. Sótt 2. júní 2012 af: http://www.crisisexperts.com/crisisdef_main.htm

Inga Hlín Pálsdóttir og Einar Karl Haraldsson (ritstjórar). (September, 2011). Skýrsla samstarfsaðila. Ríkisstjórn Íslands, Icelandair, Reykjavíkurborg, Iceland Express, Samtök ferðapjónustunnar (80 SAF fyrirtæki), Íslandsstofa og markaðsstofur landshluta. Sótt í febrúar 2012 af: http://www.idnadarraduneyti.is/media/Acrobat/Skyrslan-Inspired-by-iceland-2010-2011.pdf

James, E. H. og Wooten, L. P. (2005). Leadership as (Un)usual: How to Display Competence in Times of Crisis. Organizational Dynamics, 34(2), 141-152.

James, E. H., Wooten, L. P. og Dushek, K. (2011). Crisis Management: Informing a New Leadership Agenda. The Academy of Management Annals, 5(1), 455-493.

Kabak, I. W. og Sionkos, G. (1990). How can an industrial crisis be managed effectively? Industrial Engineering, 22(6), 18-21.

Keown-McMullan, C. (1997). Crisis: When does a molehill become a mountain? Disaster Prevention and Management, 6(1), 4-10.

Kristinn Jón Bjarnason. (2009). Stjórnun og miðlun upplýsinga á áfallatímum. Háskóli Íslands. MS ritgerð.

La Porte, T. R. (1994). A strawman speaks up: Comments on the limits of safety. Journal of Contingencies and Crisis Management, 2(4), 207-211.

Littlefield, R. S. og Quente, A. M. (2007). Crisis leadership and Hurricane Katrina: The portrayal of authority by the media in natural disasters. Journal of Applied Communication, 35, $26-47$.

Lerbinger, O. (1997). The Crisis Manager: Facing Risk and Responsibility. New Yersey: Lawrence Erlbaum Associates í Stafford, Yu og Armoo (2002).

Lettieri, E., Masella, C. og Radaelli, G. (2009). Disaster management: findings from a systematic review. Disaster Prevention and Management, 18(2), 117-136.

Matthías Sveinbjörnsson (2001). Skammtímaáhrif eldgosa á Íslandi á flugumferð og flugumferðarstjórn á Norður-Atlantshafi. Háskóli Íslands. MS ritgerð.

Marcus, A. A. og Goodman, R. S. (1991). Victims and shareholders: The dilemma of presenting corporate policy during a crisis. Academy of Management Journal, 34(5), 281-305.

Marra, F. (1998). Crisis communication plans: Poor predictors of excellent crisis public relations. Public Relations Review, 24(4), 461-474.

Marra, F. J. (2004). Excellent crisis communication: Beyond crisis plans. Í R. L. Heath og D. P. Millar (ritstj.), Responding to crisis: A rhetorical approach to crisis communication (bls. 311-325). Hillsdale, NJ: Lawrence Erlbaum Associates.

Melkonian, T. og Picq, T. (2010). Opening the "Black Box" of Collective Competence in Extreme Projects: Lessons from the French Special Forces. Project Management Journal, 41(3), 79-90.

Melkonian, T. og Picq, T. (2011). Building Project Capabilities in PBOs: Lessons from the French Special Forces. International Journal of Project Management, 29, 455-467.

Millar, D. P. og Heath, R. L. (2003). Responding to Crisis, a Rhetorical Approach to Crisis Communication. Mahwah, NJ: Lawrence Erlbaum Associates. Í Zhong og Low (2009).

Miller, G. A. og Ritchie B. W. (e.d.). A farming crisis or a tourism disaster? An analysis of the foot and mouth desease in the UK. Óbirt. Sótt 3. ágúst 2012 af http://epubs.surrey.ac.uk/1137/1/fulltext. pdf

Mitroff, I. I. (2004). Crisis leadership: Planning for the unthinkable. John Wiley \& Sons, Inc. í Paraskevas o. fl. (2013).

Mitroff, I. I. (2005). Why some companies emerge stronger and better from a crisis: 7 essential lessons for surviving a disaster. New York: American Management Association. 
Mitroff, I. I., Shrivastava, P. og Udwadia, F. E. (1987). Effective crisis management. Academy of Management Executive, 1(3), 283-292.

Óskar Örn Árnason. (2009). Gerð áfallaáætlana fyrir fyrirtæki. Háskóli Íslands. MS ritgerð.

Paraskevas, A. (2006). Crisis managment ot crisis response system? A complexity science approach to organizational crises. Management Decision, 44(7), 892-907.

Paraskevas, A., Altinay, L., McLean, J. og Cooper, C. (2013). Crisis knowledge in tourism: types, flows and governance. Annals of Toursim Research, 41, 130-152.

Pauchant, T. og Mitroff, I. (1992). Transforming the crisis-prone organization -Preventing individual, organizational, and envirionmental tragedies. Systems Research, 9(4), 71-72.

Pearson, C. (2005). Leading through crisis: 21 century global challenges. Í E. James og L. Smith (ritstj.), Crisis leadership (bls. 13-229). Charlottesville, VA: Darden Business Publishing, í James, Wooten og Dushek (2011)

Pearson, C. M. og Clair, J. A. (1998). Reframing crisis management. Academy of Management Review, 23, 59-76.

Pearson, C. M. og Mitroff, I. I. (1993). From crisis prone to crisis prepared: A framework for crisis management. Academy of Management Executive, 7(1), 48-59.

Penrose, J. M. (2000). The Role of Perception in Crisis Planning. Public Relations Review, 26(2), $155-171$.

Penrose, J. M., Rasberry, R. W. og Myers, R. J. (1997). Advanced Business Communication. Cincinnati: SouthWestern College Publishing.

Perrow, C. (1984). Normal accidents. New York: Basic Books.

Perrow, C. (1994). The limits of safety: The enhancement of a theory of accidents. Journal of Contingencies and Crisis Management, 2(4), 212-220.

Preble, J. F. (1997). Integrating the crisis managment perspective into the strategic management process. Journal of Management Studies, 34(5), 769-791.

Rassmussen, J. og Batstone, R. (1989). Why do complex organizational systems fail? Í Proceedings of a cross-disciplinary workshop in safety control and risk management. Washington, DC: World Bank.

Regína Ásdísardóttir. (2012). Áhrifapættir við krísustjórnun fyrirækja. Háskóli Íslands. MS ritgerð.

Reilly, A. H. (1987). Are organizations ready for crisis? A managerial scorecard. Columbia Journal of World Business, 22(1), 79-88.

Reilly, A. H. (1993). Preparing for the worst: The process of effective crisis management. Industrial and Environmental Crisis Quarterly, 7(2), 115-143.

Récopé, M., Liévre, P, og Rix-Liévre, G. (2010). The Commitment of Polar Expedition Members to a Project: Declared Motivation or In Situ Mobilization? Project Management Journal, 41(3), 45-56.

Rike, B. (2003). Prepared or Not...That Is the Vital Question. The Information Management Journal, 37(6), 25-33.

Ritchie, B. W. (2004). Chaos, crises and disasters: a strategic approach to crisis management in the tourism industry. Tourism Management, 25(6), 669-683.

Ritchie, B. W. (2009). Crisis and disaster management for tourism. Bristol: Channel View Publications.

Robson, C. (2002). Real World Research (2. utt.). Oxford: Blackwell.

Rochlin, G. i. (1993). Defining High Reliability organizations: A comparative framework. Í K. H. Roberts (ritstj.), New challenges to understanding organizations (bls. 11-32). New York: Macmillan Publishing Company.

Rosenthal, U., Boin, R. A. og Comfort, L. K. (2001). The changing world of crisis and crisis managment í U. Rosenthal, R. A. Boin og L. K. Comfort (ritstj), Managing crises: Threats, dilemmas, and opportunities, (bls. 5-27). Springfield, IL: Charles C.

Rosenthal, U. og Kouzmin, A. (1993). Globalizing an Agenda for Contingencies and Crisis Management: An Editorial Statement. Journal of Contingencies and Crisis Management, 1(1), 1-12.

Runólfur Smári Steinpórsson (1991). Fra metode til menneskesyn. Et notat om casemetoden i metodemæssig og videnskabsteoretisk belysing. Working paper 2 -1991. Institut for Erhvervsøkonomi og Ledelse, Handelshøjskolen i København. 


\section{STJÓRNSÝSLA}

Runólfur Smári Steinpórsson. (1995). Rannsóknir á markvissri stjórnun atvinnupróunarfélaga. Í Friðrik H. Jónsson (ritstjóri), Rannsóknir i félagsvísindum I, (bls. 379-389). Reykjavík: Félagsvísindastofnun Háskóla Íslands.

Sagan, S. D. (1993). The limits of safety: Organizations, accidents and nuclear weapons. Princeton, NJ: Princeton University Press.

Santana, G. (2003). Crisis management and tourism: beyond the rhetoric. Journal of Travel and Tourism Marketing 15(4), 299-321.

Sayegh, L., Anthony, W. P. og Perrewe, P. L. (2004). Managerial decision making under crisis: The role of emotion in an intuitive decision process. Human Resource Management Review, 14, 179-199.

Schulz, P. D. og Seeger, M. W. (1991). Corporate centered apologia: Iacocca in defense of chrysler. Speaker and Cavel, 28(1/4), 50-60.

Seeger, M. W. (1986). The challenger tragedy and search for legitimacy. Central States Speech Journal, 37(3), 147-157.

Selbst, P. (1978) í Booth, S. (1993). Crisis management strategy: Competition and change in modern enterprises. New York: Routledge.

Sellnow, T. L. (1993). Scientific argument in organizational crisis communication: The case of exxon. Argumentation and Advocacy, 30(1), 28-43.

Shrivastava, P. (1993). Crisis theory/practice: Towards a sustainable future. Industrial and Environment Crisis Quarterly, 7(1), 23-42.

Smith, D. (1990). Beyond contigency planning: Towards a model of crisis management. Industrial Crisis Quarterly, 4(4), 263-275.

Smith, D. og Elliot, D. (2006). Responding to the demands of crises: issues around future developements in theory and practice. Í D. Smith og D. Elliot (ritstjórar). Key readings in crisis management. Systems and structures for prevention and recovery (bls. 416-425). London, New York: Routledge.

Smits, S. J. og Ally, N. E. (2003). „Thinking the unthinkable“ - Leadership’s role in creating behavioral readiness for crisis management. CR, 13(1), 1-23.

Stafford, G., Yu, L. og Armoo, A. K. (2002). Crisis Management and Recovery. How Washington, D. C., Hotels Responded to Terrorism. Cornell Hotel and Restaurant Administration Quarterly, 43(5), 27-40.

Tamagno, B. (2010). The Great Ash Cloud. Geodate, 23(4), 2-5.

Turner, B. A. (1976). The organizational and inter-organizational development of disasters. Administrative Science Quarterly, 21(3), 378-397.

Turner, B. A. (1978). Man-made disasters. London: Wykeham.

Upplýsingasíða um eldgosið. (20. apríl, 2010). Mbl.is. Sótt í febrúar 2012 af: http://www.mbl.is/frettir/ innlent/2010/04/20/upplysingasida_um_eldgosid/

Wang, J. og Ritchie, B. W. (2010). A theoretical model for strategic crisis planning factors influencing crisis planning in the hotel industry. International Journal of Tourism Policy, Special Issue on Crisis and Risks in Tourism, 3(4), 297-317.

Wang, J. og Ritchie, B. W. (2012). Understanding accommodation managers' crisis planning intention: An application of the theory of planned behaviour. Tourism Management 33, 1057-1067.

Wang, J., Hutchins, H. M. og Garavan, T. N. (2009). Exploring the Strategic Role of Development in Organizational Crisis Management. Human Resource Developement Review, 8(1), 22-53.

Weiner, A. J., og Kahn, H. (1972). Crisis and arms control, í C. F. Hermann, International crises: Insights from behaviour research (bls. 21). New York: The Free Press.

Wooten, L. P. og James, E. H. (2008). Linking Crisis Management and Leadership competencies: The Role of Human Resource Development. Advances in Developing Human Resources, 10(3), 352-379.

Yin, R. K. (1989). Case Study Research: Designs and Methods. Newbury Park: Sage.

Yin , R. K. (1994). Case Study Research Methods, önnur útgáfa. Newbury Park: Sage.

Zhong, Y. og Low, S. P. (2009). Managing crisis response communication in construction projects from a complexity perspective. Disaster Prevention and Management, 18(3), 270-282.

Dúsundir strandaglópa skiluðu sér. (22. apríl, 2012). Mbl.is. Sótt í febrúar 2012 af: http://www.mbl.is/ frettir/innlent/2010/04/22/thusundir_strandaglopa_skiludu_ser/ 